\section{Labour Supply and Inequality Effects of In-Work Benefits: Evidence from Serbia}

\author{
Saša Ranđelović \\ University of Belgrade, Faculty of Economics, Serbia \\ randjelovic@ekof.bg.ac.rs \\ Jelena Žarković Rakić \\ University of Belgrade, Faculty of Economics, Serbia \\ zarkovic@ekof.bg.ac.rs \\ Marko Vladisavljević \\ Institute of Economic Sciences, Belgrade, Serbia \\ marko.vladisavljevic@ien.bg.ac.rs

\section{Sunčica Vujić ${ }^{1}$} \\ University of Antwerp and University of Bath, Department of Economics, \\ Belgium \\ suncica.vujic@uantwerpen.be
}

\begin{abstract}
Low labour market participation, together with the high effective tax wedge at low wage levels, create a fertile ground for the introduction of the in-work benefits (IWB) in Serbia. Our paper provides an ex-ante evaluation of the two IWB schemes, directed at stimulating the labour supply and more equal income distribution. The methodological approach combines the tax-and-benefit microsimulation model with the discrete labour supply model. Our results show that both individual and family-based IWB schemes would considerably boost labour market participation, although family-based benefits would have disincentivizing effects for the secondary earners in couples. Most of the behavioural changes take place among the poorest individuals, with significant redistributive effects.
\end{abstract}

Keywords: in-work benefits, labour supply, inequality, discrete choice model, microsimulation

\section{Introduction}

Low labour market participation, high informality, particularly at the bottom end of the earning distribution, and high formalization costs constitute theoretically a solid case for the introduction of making-work-pay policies, such as in-work benefits (IWB), which are means-tested benefits conditional on employment status. These policies have become popular in many European countries trying

\footnotetext{
1 Corresponding author: Sunčica Vujić, Department of Economics, University of Antwerp, Prinsstraat 13, 2000 Antwerp, Belgium. Email: suncica.vujic@uantwerpen.be. Tel.: +32 32654902.
}

ORIGINAL SCIENTIFIC PAPER

RECEIVED: JULY 2019

REVISED: AUGUST 2019

ACCEPTED: SEPTEMBER 2019

DOI: 10.2478/ngoe-2019-0010

UDK: 004.775:339.137.2:005.412

JEL: J22, H24, D31, I32

Citation: Ranđelović, S., Žarković Rakić, J., Vladisavljević, M., \& Vujić S. (2019).

Labour Supply and Inequality Effects of In-Work Benefits: Evidence from Serbia. Naše gospodarstvo/Our Economy, 65(3), 1-22. DOI: 10.2478/ngoe-2019-0010

\section{NG OE}

NAŠE GOSPODARSTVO OUR ECONOMY

\section{Vol.65 No.3 2019}

pp. $1-22$ 
to promote labour market participation and work formalization, particularly among low-paid workers. Empirical studies confirm that the IWB policies have been effective in tackling the above-mentioned labour market problems in developed countries, particularly in the United States (US) and the United Kingdom (UK) (Blundell et al., 2000; Blundell \& Hoynes, 2004; Meyer \& Rosenbaum, 2001; Orsini, 2006). However, the empirical literature on the effectiveness of these policies in the European developing and transition economies is scarce. Our paper attempts to fill this gap.

A high labour force participation rate is important for economic growth, competitiveness, poverty reduction, and the political and social stability of a country, especially with an aging population. These are some of the reasons why the European Union 2020 (EU 2020) strategy set the employment rate target for 20- to 64-year-olds at $75 \%$ (European Commission, 2010). According to the Statistical Office of the Republic of Serbia (SORS, 2016), the country's average (over four quarters) labour force participation rate of the working age population (15- to 64-yearolds) was $60.5 \%$ in 2016 , while the employment rate was $45.2 \%$; both of these indicators are far below the EU-28 average of $73 \%$ for the labour force participation rate, and 71\% for the employment rate in 2016 (Eurostat, 2019a; OECD, 2019). Inactivity is particularly high among lowskilled, low-income earners. Serbia's active population will further decline in the current decade, due to the exit of baby boomers from the labour market, and the increasing outbound migration (Arandarenko et al., 2012). Since the onset of the global economic crisis, in addition to the declining labour market participation, the informality rate has been on the rise, being particularly high in the agriculture and self-employment sectors, thus further reducing the reservoir of formal labour market participation.

Following the well-established theoretical base and empirical framework for the evaluation of labour market effectiveness of the IWB policies (Bargain \& Orsini, 2006; Blundell, 2000; Immervoll \& Pearson, 2009; Saez, 2002), our research combines the EUROMOD-based tax-and-benefit microsimulation model for Serbia (SRMOD) with a structural labour supply model, in order to evaluate the effects of the IWB policies, as well as the interplay between the IWB policies and other tax-and-benefit policies, on labour supply and income distribution in Serbia.

The aim of this paper is to provide an empirical estimation of labour supply effects of in-work benefits for a transition country. These results will be benchmarked to the results on the effects of IWBs for countries that are similar to Serbia in terms of labour market performance (high unemployment and inactivity rates, particularly for young people and women) and features of tax and benefit systems (lacking social assistance benefits). The results will be compared with those for other Western Balkan countries, as well as Portugal, Spain, Italy and Greece (which have similar labour market characteristics as Serbia). In addition, the results on labour supply elasticities will be compared to those for developed and other transition countries.

We see a threefold contribution of our paper to the existing literature. First, bearing in mind that the effectiveness of the IWB policies depends on their design, as well as on the institutional characteristics of a targeted country, our paper constitutes a new methodological framework taking into account the characteristics of the labour market of a transition country. The existing literature has mostly focused on the developed economies, while the empirical literature for the European transition economies, to the best of our knowledge, is limited to the evidence for Slovenia (Kosi \& Bojnec, 2009), Poland (Myck et al., 2013), Macedonia (Mojsoska et al., 2015) and Serbia (Clavet et al., 2019; Ranđelović \& Žarković-Rakić, 2013; Žarković-Rakić et al., 2016). Second, since low labour market participation, high informality and high formal activation costs are common features of the Western Balkan economies, while the IWB policies are almost non-existent, the empirical results for Serbia may represent a considerable contribution not only to the existing empirical literature but also to a discussion on introducing making-work-pay policies in the region. Third, we provide evidence on the effectiveness of the IWB policies with respect to different family structures (singles and couples) and with respect to the position of women in the labour market. This is particularly important taking into account that inactivity rates of women in Serbia are considerably higher than those of men (76.6\% and 63.8\%, respectively, in the last quarter of 2016; SORS, 2016).

The results obtained in this paper suggest that both individual IWB (IIWB) and family IWB (FIWB) would trigger a decline in labour market non-participation: the effects of FIWB are larger for singles, while the IIWB would have higher impact on the labour supply of individuals in couples. At the same time, the FIWB would have somewhat larger effects for single women than for men, the effects of IIWB being the opposite, while no significant difference in terms of labour supply reaction to the IIWB and the FIWB by gender is found in the case of coupled individuals. The policy is expected to yield positive effects on inequality, since most of the labour activation would happen at the lower end of the income distribution. The difference in the size of the effects of IIWB and FIWB, depending on the income level and marital status, is the consequence of the difference in the design of the IIWB and FIWB policies but also the result of variation in labour supply elasticities by income levels and marital status. 
The remainder of the paper is organised as follows. The next section provides an explanation of the participation and formalization disincentives coming from the tax-and-benefit system design. Section 3 deals with the analysis of the IWB design and the overview of empirical literature on the IWB policies. In section 4 , the data and methodology are presented, while the results are presented and discussed in section 5. Section 6 concludes the paper.

\section{Tax-and-benefit System in Serbia: Why Working at Low Wage Levels Does Not Pay?}

In this section, we provide further information on the characteristics of the labour market in Serbia in general and the tax-and-benefit structures in particular. Serbia's labour market performs considerably worse when compared to most other European economies. The labour market participation rate currently stands at $63.4 \%$, while the unemployment rate is $18.8 \%$. Inactivity and unemployment rates are particularly high among low-educated individuals. Living Standards Measurement Survey (LSMS) 2007 data, used in this paper, show that non-participation rates for those with primary education (55.5\%) are significantly higher than for those with secondary (30.0\%) and tertiary education (18.7\%). At the same time, women are in a particularly difficult labour market position. On average, they face 16.6 percentage point higher inactivity rates and 4.7 percentage point higher unemployment rates than men (Table 1).

Arandarenko and Vukojević (2008) show that the tax-benefit wedge in Serbia is rather regressive at the bottom of wage distribution, due to the high minimum social security contribution base, relatively high social contribution rates, low non-taxable threshold (for personal income taxation) and withdrawal of means-tested benefits. This has been confirmed by the World Bank study for Serbia (Koettl, 2010), which calculated the Implicit Costs of Formalization (ICF), defined as the share of income that an informal worker has to give up in order to formalize work, showing disincentives for formalization stemming from labour taxation and benefit withdrawal. The study shows that a single person with no children who earns less than the minimum wage in the informal sector has to give up between $40 \%$ and $75 \%$ of income in order to formalize work.

Labour market participation in Serbia is among the lowest in Central and Eastern Europe (CEE), being close to the activity rates in the Western Balkan countries, while the female participation rate is considerably lower than the male participation rate (Table 2). At the same time, income inequality in Serbia is among the highest in Europe (Davies, 2018).

Table 2. Labour market participation rates in the CEE (2014)

\begin{tabular}{llll} 
& Total & Women & Men \\
\hline Czech Republic & 73.3 & 65.6 & 80.9 \\
\hline EU-28 & 72.1 & 66.0 & 78.2 \\
\hline Slovenia & 70.9 & 67.4 & 74.2 \\
\hline Slovakia & 70.2 & 62.7 & 77.7 \\
\hline Bulgaria & 68.1 & 64.2 & 72.0 \\
\hline CEE-average & 67.8 & 61.3 & 74.3 \\
\hline Poland & 67.3 & 60.5 & 74.2 \\
\hline Romania & 65.0 & 57.3 & 72.8 \\
\hline FYR of Macedonia & 64.6 & 51.5 & 77.3 \\
\hline Hungary & 64.6 & 58.6 & 70.6 \\
\hline Croatia & 64.1 & 58.6 & 69.7 \\
\hline Albania & 63.0 & 51.7 & 74.2 \\
\hline Serbia & 61.7 & 53.9 & 69.7 \\
\hline Montenegro & 59.2 & 52.3 & 66.1 \\
\hline Bosnia and Herzegovina & 54.5 & 42.1 & 67.1 \\
\hline
\end{tabular}

Source: World Bank Database

Low-education attainment coupled with a lack of work experience generates low earning capacity in the labour market. When earnings or potential earnings are low, incentives to seek employment or stay in employment are usually limited. Incentive problems are aggravated by high tax burdens on labour income and by cuts in social benefits designed to provide at least some safety nets for those with no or very low income (Immervoll \& Pearson, 2009).

Table 1. Non-participation and unemployment rates by level of education and gender (\%)

\begin{tabular}{lccccccc} 
& & & & & \multicolumn{3}{c}{ Education level } \\
\cline { 5 - 8 } & & Total & Men & Women & Primary and less & Secondary & Higher \\
\hline Unemployment rate & 13.9 & 11.8 & 16.5 & & 14.9 & 15.4 & 7.9 \\
\hline Inactivity rate & 36.6 & 27.3 & 43.9 & 55.5 & 30 & 18.7 \\
\hline
\end{tabular}

Notes: Working age population (15-64 years)

Source: Authors' calculations based on LSMS, 2007. 
The labour tax wedge in Serbia for those with low earnings (67\% of average wage) is among the largest in the CEE and is also higher than the EU-28 average (Figure 1). In addition, the degree of progressivity of labour taxation in Serbia is among the lowest in the CEE. When the wage increases from $67 \%$ of the average wage to $167 \%$ of the average wage, the labour tax wedge (as per cent of labour costs) in Serbia rises only by 1.3 percentage point, while in the CEE and the EU-28 the rise is considerably steeper 6.4 percentage point and 8.1 percentage point, respectively (Figure 1).

The relatively high labour tax burden of low-paid jobs and low progressivity are the consequences of several factors, the most important being the mandatory minimum social security base and the sudden withdrawal of means-tested benefits upon formal employment. ${ }^{2}$ The minimum base, which is mandatory for every worker, is set at $35 \%$ of the average wage, implying that when the actual wage is below the minimum base, the social contributions are calculated on the minimum base. Given that the base is effectively not adjusted for working hours, the low-paid part-time jobs are exposed to a high social contribution burden.

2 This is a peculiar feature of the social security contribution systems in the Western Balkan region. The most drastic example is Macedonia, where the mandatory base is set as high as 50\% of average wage.
Additionally, the labour tax reform that was introduced in 2001 brought about the abolishment of fringe benefits. The two most important benefits of this kind were food allowances (paid monthly) and an annual leave benefit. Given that both fringe benefits were not taxed and were paid in equal amounts to each worker, the abolishment of these benefits contributed to the regressive character of the labour tax system, which was in effect until 2007 (Arandarenko \& Vukojević, 2008). The changes to the labour tax system that took place in 2007 envisaged a cut in the wage tax rate between $12 \%$ and $14 \%$ and the introduction of the zero tax bracket (up to 5,000 Dinars (i.e., 63.1 Euro), or approximately $15 \%$ of the average wage). However, the tax burden on labour did not change considerably, given that the social security contributions dominated the tax wedge. ${ }^{3}$

Another peculiarity of the Serbian labour market relates to relatively high informality. As put forward by Krstić and Sanfey (2011), between 2002 and 2007 informal work rates in Serbia rose despite strong economic growth and the improved business climate in the country. The authors argue that one possible reason for this unexpected result

3 In 2001, contributions were set at $32.6 \%$ of the gross wage, equally split between employers and workers. The first increase in mandated contributions occurred in 2003, with an increase of 1 percentage point. The next modification was made in 2004, and currently the overall social security tax rate amounts to $35.8 \%$ of gross wage: $22 \%$ for old age, disability and survivors’ pensions, $12.3 \%$ for health insurance, and $1.5 \%$ for unemployment insurance.

Figure 1. Labour tax wedge and progressivity of labour taxation in the CEE (2014)



Source: Authors' calculations based on the Eurostat Labour Force Survey (LFS) 2014 data and International Labour Organization (ILO) 2014 data 
is the regressive character of the labour tax system that was introduced in 2001 and that was applied until January 2007. The incentives to join the formal economy were diminished for both workers and employers. However, it should be noted that the high informality rate in Serbia was to a large extent driven by informal work in agriculture and self-employment, where informal workers accounted for $87 \%$ and $53 \%$ of the total number of workers, respectively, while the average informal wage-employment was considerably lower, with a $10 \%$ share in the total number of wage-employees in 2007, thus being below the average for Southern Europe ${ }^{4}$ (Hazans, 2011).

Besides labour taxation, the social benefits design is another piece of the puzzle necessary to explain the high levels of inactivity and informality among the working-age population in Serbia. Once a person has a formal income on her/ his record, major income-tested benefits (social assistance and child allowance in particular) will be decreased by the total amount of earned income or completely withdrawn. In their study on inactivity in the Serbian labour market, Arandarenko et al. (2012) show that a person receiving 4 Southern Europe constitutes Italy, Spain, Greece, Portugal, and
Cyprus. social benefits does not have an incentive to search for a job offering a salary below $20 \%$ of the average gross wage, which is equivalent to a part-time job equalling 20 hours at the minimum hourly wage. Mainly due to the mandatory minimum social security contribution base, net income for this individual becomes equal to the amount of social assistance benefit. Therefore, the so-called mini-jobs and midi-jobs (mainly part-time jobs) are not economically attractive for low-wage earners.

As a result of the minimum social contribution base, sudden withdrawal of the means-tested benefits and other mentioned factors, the tax wedge distribution is regressive up to $33 \%$ of average wage, afterwards being only slightly progressive (Figure 2). At the same time, the implicit formalization costs are the highest at the very bottom of wage distribution. ${ }^{5}$ Such design of the tax-benefit scheme creates considerable disincentives for labour market participation of low-skilled individuals.

\footnotetext{
5 Implicit formalization costs are calculated as the percentage of initial income that a household has to give up in order to switch from the informal to the formal sector, assuming the gross wage offer is unchanged.
}

Figure 2. The tax wedge, implicit costs of formalization and the marginal effective tax rate for singles with no children in Serbia (2009)

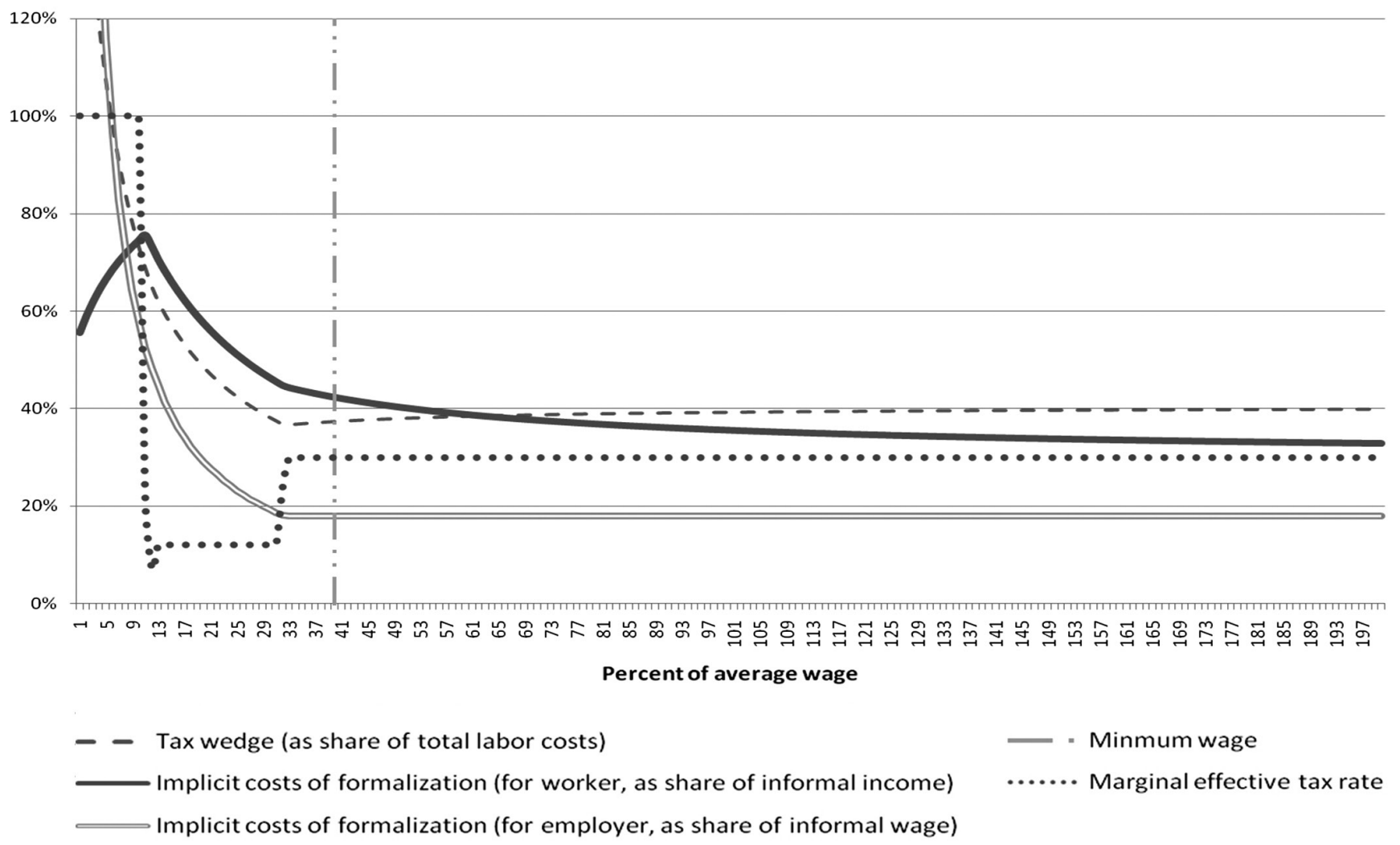




\section{In-Work Benefits Objective, Design and Labour Supply Effects: Literature Review}

The intention of policymakers to address the issue of insufficient labour market participation and very low participation of low-skilled, low-paid workers (thus, at the same, time tackling inequality and poverty issues) has brought the design of tax-and-benefit policies and their interplay back into the focus of empirical literature and discussions. Measures directed at increasing the income of persons with a low earnings capacity have mostly centred on the introduction of the IWB policies. The IWB policies are designed to promote work and reduce poverty by generating a difference between the incomes of working people and the counterfactual situation, that is, the incomes they would have if they were out of work. Additionally, the IWB schemes contribute to higher formality by effectively reducing the labour tax wedge and thus encouraging wage formalization.

The introduction and expansion of the IWBs in the European countries has been inspired by the Earned Income Tax Credit (EITC), introduced first in the US, and the subsequent Working Family Tax Credit (WFTC) practice in the UK. The main motivations for the introduction of these policies in Europe and North America during the early 1990s were the low levels of labour force participation and employment experienced by certain specific demographic groups of working age (Blundell, 2006). In a theoretical framework, Kolm \& Tonin (2011) show that IWBs can be extended to larger sections of the workforce and to other countries. Nowadays, most of the OECD countries apply some types of the IWB programs in order to boost labour market activity and employment (Immervoll, 2012; Immervoll \& Pearson, 2009). Even though there are differences among the countries in terms of the design of the IWBs, all employment-conditional measures use at least one of the following criteria to assess eligibility and determine the amount of benefits: having children, working a minimum number of hours, and receiving income from work or entering into employment. Most of these benefits are proportional to gross income up to a maximum amount, afterwards being gradually withdrawn. In other words, they are characterised by the gradual phase-in and phase-out brackets, as a mean of targeting individuals with specific earnings levels or working hours.

An important aspect of the IWB design is the choice of the unit used to assess income (Orsini, 2006; Orsini \& Bargain, 2006). In some countries, eligibility for benefits is assessed at the household level, while in other countries it is focused on individuals. Family IWBs are more effective in boosting the labour supply of single individuals, due to discouraging effects on the second earners in households, who in most cases are women (Eissa \& Hoynes, 1998). However, in certain cases, family benefits can have both redistributive and incentive effects. This is the case with lone parents that constitute a large part of poor households (Orsini \& Bargain, 2006). On the other hand, individual-level benefits have greater work-incentive effects than do family-based benefits, since they do not discourage the participation of second earners in a couple (Blundell et al., 2000; Orsini \& Bargain, 2006).

Most evaluations of labour supply effects and distributional effects of the IWB policies in European countries are ex ante evaluations based on a behavioural microsimulation framework. For example, Blundell et al. (2000) have estimated the labour supply preferences on data not affected by the policy reforms, which were then used to simulate the impact of the introduction of the WFTC in the UK. The authors have found that the introduction of the WFTC leads to an increase in labour market participation rates for lone mothers and a small decline in labour market participation amongst women in couples, with no net effect on the labour market participation rates of men in couples. ${ }^{6}$ The results are consistent with the findings of Brewer et al. (2006). Bell (2005) has found that the decline in child poverty between the fiscal years 2002 and 2004 can be attributed to the introduction of the WFTC program in the UK. Brewer (2006) also noted that the WFTC program reduced the number of families in poverty. St Martin \& Whiteford (2003) have estimated that the WFTC program produced about 100,000 new jobs, while the cost of this policy was about 1\% of GDP. Orsini \& Bargain (2006) have simulated the British WFTC scheme and the individualized wage subsidy scheme for Finland, France, and Germany, countries which have experienced severe poverty traps. They have found that the participation of married women declined in all three countries after the introduction of the WFTC, the negative effect being only partially offset by the positive impact of the reform on single women's labour supply (in Finland and in Germany). On the other hand, they have found that individual IWB encouraged married women to take jobs. The effects in Finland were lower than in other countries, mainly due to the relatively small labour supply elasticity. Both programs were found to have had significant anti-poverty effects. Haan \& Myck (2007) also find strong disincentivizing effects of the British style IWB on coupled individuals, if implemented in Germany. Myck et al. (2013) have found evidence on the IWB-related disincentives on the work of secondary earners in Poland and provide proposals to tackle this issue. Saez (2002) has evaluated the making-work-pay policies in the US and showed that the IWB policies provide an optimal income transfer program when the labour supply choice is

\footnotetext{
${ }^{6}$ For the evaluation of the EITC, see Scholtz $(1994,1996)$, Eissa and Hoynes (1998), Eissa and Liebman (1996), and Meyer and Rosenbaum (2000).
} 
whether or not to work (extensive margin). On the other hand, if the labour supply choice is about intensity of work on the job (intensive margin), then the optimal transfer program is a classical Negative Income Tax program with a large guaranteed income-support schemes, which are taxed away at high rates.

The effectiveness of making-work-pay policies is fundamentally dependent on the labour market structure, inherent elasticities and the institutional set-up. Therefore, switching to an environment where participation is low, unemployment is high and institutions are weaker may change the expected outcomes of the IWB policies. With respect to this, several papers have emerged focusing on the southern European countries (particularly Italy), which share these features. Figari (2015) finds that the family IWB in Italy triggers an average increase of female labour supply by 3 percentage points, the individual IWB having stronger incentive effects on coupled women, since their labour supply increase is estimated at 5 percentage points. He also finds that most of the labour supply reactions induced by the IWB take place among the poorest individuals, with important redistributive effects. Similar results for Italy, especially for couples with children, are found in De Luca et al. (2013). Colonna \& Marcassa (2013) show that the working tax credit in Italy boosts the labour force participation rate, particularly among unskilled and low-educated women.

Late transition economies of Southeastern Europe have even more unfavourable labour market features than the Southern European countries, while making-work-pay policies (and empirical literature on this topic) are largely absent. Mojsoska et al. (2015) use a microsimulation framework to assess the impact of the hypothetical IWB schemes in Macedonia and find that family IWBs are more effective in promoting the labour activation of singles, while individual benefits are more effective in the case of couples, with the effects in both cases being concentrated at the bottom of the income distribution with poverty reduction effects. Using the tax and benefit micro-simulation model for Serbia (SRMOD), Ranđelović and Žarković-Rakić (2013) provide empirical evidence on the incentive and distributional effects of the abolishment of the mandatory minimum social security contribution (SSC) base, showing that the reform would reduce effective average tax rates by more than it would reduce effective marginal tax rate, while the impact of the reform on the overall level of inequality, measured by the Gini coefficient, would be small. Žarković-Rakić et al. (2016) evaluates the impact of the minimum SSC base reform scenarios in Serbia on labour supply and employment formalization and conclude that the proposed reform would not significantly contribute to the transformation of informal full-time to formal full-time jobs. Clavet et al. (2019) evaluate the labour supply and distributive effects of several reform strategies concerning two major social transfers in Serbia: child allowance and social monetary assistance. The results show that, in a context of a low labour participation rate, and high unemployment and informality rates, a benefit strategy is by far the more cost-effective option for reducing child poverty than an employment strategy that aims to raise the work incentives for parents.

\section{Methodology: Behavioural Microsimulation Model, Data and Policy Reform Design}

\section{Model and Data}

In order to analyse the potential effects of policy measures on labour supply incentives and income redistribution, this paper combines the tax-and-benefit microsimulation model for Serbia (SRMOD), which is based on the EUROMOD platform (Sutherland \& Figari, 2013), with a structural, discrete choice, labour supply model. ${ }^{7}$ Similar to other microsimulation models, SRMOD is a tax-and-benefit calculator based on the micro-data on income, earnings, labour force participation and socio-demographic variables, allowing us to reproduce the budget constraint for each household (i.e., the latent set of working hours and household disposable income alternatives), while the labour supply model rationalizes observed behaviour.

The policies simulated in SRMOD refer to Living Standards Measurement Survey (LSMS) dataset in 2007 as the baseline year. The LSMS in 2007 is a nationally representative survey (on 17,735 individuals divided in 5,575 households) conducted by the Statistical Office of the Republic of Serbia in cooperation with the World Bank. We have opted to use the LSMS dataset because it was the only comprehensive survey in Serbia providing the amount of social and economic information required for tax-and-benefit microsimulation modelling. Although we use the data from 2007, labour market indicators are similar to 2015 not only in absolute but also in relative terms, across both gender and levels of educational attainment. According to the Labour Force Survey Data for Serbia in 2015, unemployment and inactivity rates for women were 4 and 15 percentage points higher than for men, respectively, which is comparable to the situation in 2007. Further, those having primary education or less still have significantly higher inactivity rates compared

\footnotetext{
The main advantage of using discrete-choice instead of continuous labour supply models comes from the possibility of accounting for taxes and benefits (i.e., non-linear and non-convex budget sets; Van Soest, 1995), which is why these models have been extensively used for an ex-ante evaluation of hypothetical tax-and-benefit reforms.
} 
to individuals with secondary or tertiary education. Since the main labour market indicators (participation, employment, unemployment) were almost unchanged in 2015 compared to 2007, the dataset may still be regarded as relevant. The LSMS dataset contains separate data on formal and informal income from employment, self-employment and agriculture. According to the macro-validation results, formal employment incomes are lower than the actual amounts by $7 \%$, with the difference being attributed to informal salaries and wages. In the case of agricultural and self-employment earners, the share of informal income in the actual income is much larger - 56\% and $22 \%$, respectively. Taxes, social contributions and benefits in SRMOD are simulated using the data on formal income, since both taxes and benefits are determined based on the formal income.

Personal income tax, social security contributions and major means-tested benefits (monetary social assistance and child allowance) are the main tax-benefit programs simulated in SRMOD, while for most of the non-means-tested benefits (e.g., birth grant, old age pensions, unemployment benefits, caregiver allowance, maternity and childcare benefits) reported values are used, which is a common approach in other EUROMOD and related models, determined by the data availability. ${ }^{8}$ Personal income tax is simulated using the rules applicable in a year of the given dataset, which means that incomes from various sources are taxed at different, but always flat, tax rates ranging between $10 \%$ and $20 \%$. Wages, as the largest source of income in Serbia, are taxed at the flat rate of $12 \%$, applied to the amount of gross wages exceeding non-taxable threshold, which in 2007 amounted to RSD 5,050 per month.. Social security contributions are calculated on all gross labour incomes, applying the rate of $22 \%$ for pension and disability insurance contributions, $12.3 \%$ for health insurance and $1.5 \%$ for unemployment insurance and the regulations on the minimum base (35\% of the average wage) and the maximum base (five times average wage) for social contributions. All social contributions are equally split among employers and employees. Monetary social assistance is the last-resort financial assistance program, means-tested against the total income (per household member), as well the land and buildings area (per household member) owned by the household. Thus, individuals or families who pass the means test are entitled to the benefit calculated using the following scale: i) for the first adult person in a family, the basic amount (RSD 7,628 per month) multiplied by 1; ii) for each additional adult person in a family, the basic amount multiplied by 0.5 ; and iii) for each child up to the age of 18 , the basic amount multiplied by 0.3 . Individuals incapable of work, and families with all members incapable

\footnotetext{
8 Detailed descriptions of the policies simulated in SRMOD are provided in Ranđelović and Žarković-Rakić (2013).
}

of work, as well as lone-parent families with one or two children (below the age of 18) are entitled to an increased amount of this benefit (by 20\%). Child allowance is the means-tested benefit aimed at reducing poverty in families with children. Eligibility is limited to the households in which total monthly net income per family member does not exceed a certain threshold (RSD 4,705 per month), while the amount of the benefit is flat (RSD 1,490 per month), with only the first four children in the family being entitled to this benefit.

The results of macro-validation of SRMOD simulations are satisfactory, since the margin between the simulated income tax and social contributions compared to the administrative data ranges between $5 \%$ and $20 \%$, a large share of discrepancy being attributed to the underreporting of income and sampling issues in the survey, since the average wage in the dataset is $8 \%$ lower than the one published by the Statistical Office (Ranđelović \& Žarković-Rakić, 2013). The discrepancy between the simulated benefits and the amounts disclosed in administrative datasets is even lower, ranging from $5 \%$ to $15 \%$. Using the data on market income, simulated taxes, social contributions and means-tested benefits, as well the reported (non-simulated) benefits, SRMOD provides calculations of the household disposable income, replacement rates, and effective marginal tax rates.

In this paper, we estimate two discrete choice labour supply models, thus specifying separately preferences of singles and couples. Labour supply model estimation is restricted to the 'labour market flexible' individuals whose labour supply behaviour can be captured by the econometric model. Therefore, disabled individuals, students, pensioners, and self-employed individuals are dropped, which is a common approach in the labour supply literature (Blundell et al., 2000; Figari, 2015; Haan \& Myck, 2007). An additional reason to exclude the self-employed from the model is related to difficulties with measurement of their true hours and wages (Löfler et al., 2014). Descriptive statistics of the estimation sample are provided in the Appendix (Table A1). Since the model mostly deals with wage employment, similar to the literature on Southern European countries, it is focused on formal work, with the similar or slightly higher wage-employment informality (De Luca et al., 2013, Figari, 2015). Discrete choice labour supply models are based on the assumption that a household can choose among a finite number of $\mathrm{J}+1$ working hours. Each hour $\mathrm{j}=0, \ldots, \mathrm{J}$ corresponds to a given level of disposable income of individual, and each discrete bundle of working hours and income provides a different level of utility. In other words, the utility of a household $i$ making the choice $\mathrm{j}, V_{i j}$, is given by:

$V_{i j}=U\left(H f_{i j}, H m_{i j}, I_{i j}, Z_{i}\right)+\varepsilon_{i j}$ 
We use the quadratic specification for the deterministic part of the utility function, as in Blundell et al. (2000). The deterministic part of the utility function depends on the spouses' working hours $\left(H f_{i j}, H m_{i j}\right)$, disposable income $\left(I_{i j}\right)$, and the vector $Z_{i}$ of describing households' characteristics (age, gender, education level of the household members and parenthood). For a couple, choices $\mathrm{j}=0, \ldots, \mathrm{J}$ correspond to all combinations of the spouses' discrete working hours. Starting from the empirical distribution of the working hours, we assume that each partner may work 0,20 , or 40 hours, corresponding to non-participation, part-time, and full-time work. This implies that a couple can choose among nine alternative combinations of working hours. Each alternative is characterised by a triplet of disposable income and working hours of female and male partner.

Disposable income, $I_{i j}$ is the tax-benefit function $(\mathrm{G})$, which depends on female and male hourly wages $\left(W f_{i j}, W m_{i j}\right)$ and hours of work $\left(H f_{i j}, H m_{i j}\right)$, as well as on the non-labour income $\left(Y_{i}\right)$ and households' characteristics $\left(Z_{i}\right)$ :

$I_{i j}=G\left(W f_{i j}, W m_{i j}, H f_{i j}, H m_{i j}, Y_{i}, Z_{i}\right)$

When estimating the discrete labour supply model, hourly wage is not observed for inactive and unemployed workers in the sample. Since their labour market status is correlated with the potential wage offer, dropping unemployed and inactive workers would trigger selection bias. In order to avoid this,, the Heckman selection model is used in order to impute hourly wages for males and females supplying zero hours (Heckman, 1976; 1979). We then use SRMOD to calculate their labour and disposable incomes corresponding to a discrete set of working time alternatives.

Once disposable income $I_{i j}$ is obtained for all the choices $(j)$ and all the individuals (i), the conditional logit function is estimated by the maximum-likelihood estimation approach, in order to estimate preference parameters of the utility function. Labour supply effects are estimated by comparing the predicted probability of each choice under the pre-reform and post-reform conditions.

In countries with the constraint on the demand side of the labour market (which is the case in Serbia), the labour supply model is partial. Although this is a limit of the labour supply approach to evaluation of the labour market effects, most of the previously mentioned empirical studies on makingwork-pay policy effects take into account only the labour supply response, even though the authors recognize the relevance of the demand constraint. There are also studies that implicitly encompass the labour demand effects by using involuntary unemployment to describe the labour demand reaction (Bargain et al. 2010). However, use of this approach is limited to the datasets that provide the information on involuntary unemployment, which is not the case with the LSMS for Serbia in 2007.

\section{Policy Design}

Although most OECD countries apply some sort of IWBs (OECD, 2009), the American EITC and the British WFTC are the most commonly analysed and discussed. The British scheme of IWBs has recently been considered as a potential model to be introduced in the Southern European countries (e.g., Italy, Spain, etc.), in order to support the labour market participation of women and poor households (Owens, 2006; Figari 2010).

Given the pioneering role of the British experience in these policies, we simulate the family based IWB using the British WFTC structure as an example. The ratio between the thresholds of eligibility and the maximum amounts of the benefit in this paper is calibrated, in order to get fiscal costs of $0.14 \%$ of Gross Domestic Product (GDP), in static terms, which is equivalent to half of the monetary social assistance program costs. Currently, a half of the total number of monetary social assistance beneficiaries are physically healthy individuals, which has urged the government to propose measures aimed at activating benefit recipients. Therefore, the government has recently introduced a wage subsidy equal to the minimum wage for part-time work, which is available to physically healthy social assistance recipients who accept work offered by the National Employment Bureau. Family IWB (FIWB2) and FIBW3 policies (defined later) proposed in this paper are, to a certain extent, similar to the proposed wage subsidy scheme, which was an additional reason to opt for the same budgetary costs. When deciding on the total budget, we have also taken into account the need to achieve a substantial increase in wages (of low-wage earners), thus creating the solid ground for considerable labour supply response, while at the same time taking into account the political and fiscal sustainability of the policy.

Depending on the structure of the family, there are three types of family IWB (FIWB), and one individual IWB (IIWB). FIWBs are differentiated by the family structure (single vs. lone parents and couples), as well as by the number of working hours, which is why there are three alternative FIWB schemes (Table 3). The amount of benefits is fixed, and the eligible family receives them until their labour incomes and pensions reach certain threshold, with the benefit being gradually phased out afterward (by 0.37 dinars for every additional dinar of income) and at some point reaching zero. In order to have working incentives not only for people with low earnings but also for people with low hourly wages, an individual-based benefit scheme 
Table 3. Parameters of the family and individual in-work benefits (monthly amounts)

\begin{tabular}{lcccccc} 
& FIWB1 & FIWB2 & FIWB3 & IIWB \\
\hline Type of tax unit & Single & $\begin{array}{c}\text { Couples with children } \\
\text { and lone parents }\end{array}$ & $\begin{array}{c}\text { Couples without } \\
\text { children }\end{array}$ & $\begin{array}{c}\text { Lone parents and } \\
\text { couples }\end{array}$ & All \\
\hline Assessment unit & Family & Family & Family & Family & Individual \\
\hline Minimum working hours per week & 40 & 16 & 30 & 40 & 16 \\
\hline Amount of benefit & 6,667 & 8,333 & 10,000 & varying \\
\hline Withdraw start threshold & 15,000 & 17,500 & 19,167 & 14,333 \\
\hline Phase-in rate & - & - & - & 0.36 \\
\hline Phase-out rate & 0.37 & 0.37 & 0.37 & 0.37 \\
\hline
\end{tabular}

Notes: FIWB refer to the Family IWB, IIWB refer to the individual IWB; 1, 2 and 3 refer to different parameterization of FIWB programs

IIWB is developed. IIWB treats all the workers in the same manner regardless of their family status, so all individuals who work at least 16 hours per week and whose income is below the stipulated threshold are entitled to the benefit, which is gradually phased in (0.36 dinars of benefits for every earned dinar). When income reaches certain threshold, gradual phase-out (at the rate of 0.37 dinars for every additional dinar of income) begins.
Although the total costs of both IIWB and FIWB are the same, the mean FIWB amounts to RSD 5,020 (approximately 14\% of the average wage), while mean IIWB equals RSD 3,426 (approximately $9 \%$ of the average wage). The mean amount of IIWB is the same for singles and coupled individuals, while the average FIWB is somewhat lower for singles. The effects of the IWB schemes on disposable income of the typical (hypothetical) households are presented in Figures 3 and 4.

Figure 3. Effects of the IWB schemes on disposable income: singles with no children

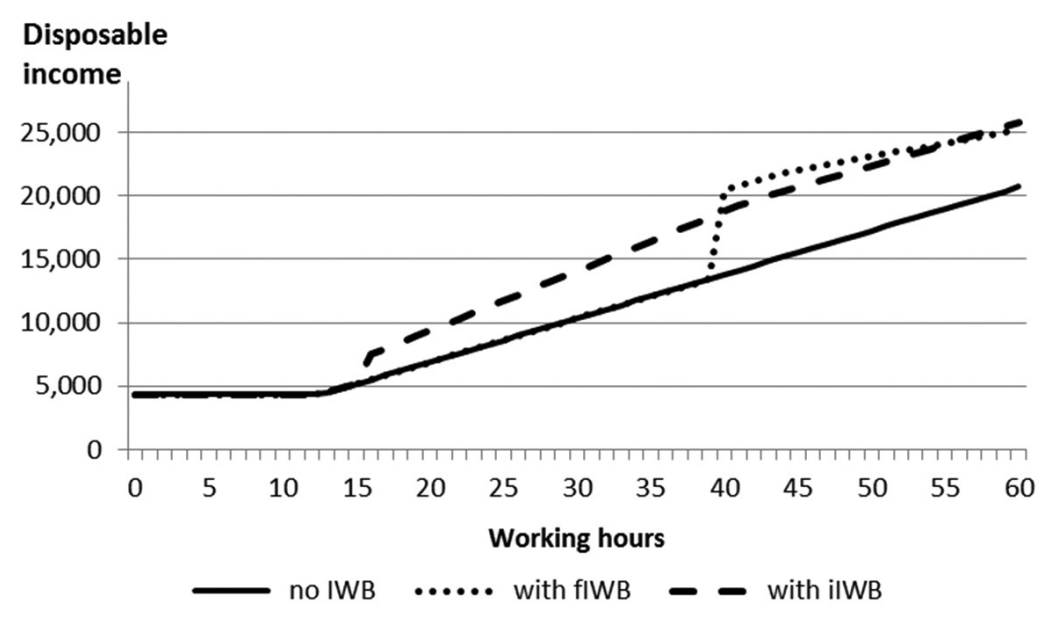

Figure 4. Effects of the IWB schemes on disposable income: couples with two children






\section{Results}

\section{Heckman Wage Equation, Utility Function and Labour Supply Elasticities}

The estimated coefficients of the Heckman wage and selection equations are presented in the Appendix (Table A2). The coefficients have the expected signs and magnitudes. The estimated parameters of the utility function are also presented in the Appendix (Tables A3a for singles and Table A3b for couples). Utility functions describe the marginal utility (disutility) of income and work, taking into account the heterogeneity of preferences captured by the demographic characteristics (age, education and parenthood) and the fixed costs of working. Our results on the utility function parameter estimation are in accordance with the expectations, indicating positive and diminishing marginal utility of income and increasing marginal disutility of working hours for both singles and couples. The results further show that the marginal utility of income decreases with age (at a diminishing rate) for singles and married men and with the level of education (except for single men). On the other hand, the marginal disutility of working hours increases with age and level of education for both singles and couples. Furthermore, parenthood has no significant impact on preferences of singles due to a small sample size of single mothers and fathers, while increasing the utility of income for couples. The results are robust to changes of the sample of the non-employed (unemployed versus inactive) and to the exclusion of informal employment. ${ }^{9}$

Starting from the estimated utility function parameters, we have calculated the labour supply elasticities at both extensive (labour force participation) and intensive margins

\footnotetext{
9 For inactive and unemployed workers in the sample, hourly wage is not observed. In order to calculate disposable income for these workers, the hourly wage rate is estimated on the whole sample of working-age individuals (employed, unemployed or inactive) and imputed for males and females supplying zero hours. Inactivity is the extreme form of unemployment in the sense that inactive workers are unemployed, are not looking for a job, and are not immediately available for work when a job is offered to them. Classification into the inactive population is based on the self-evaluation of individuals about their efforts to search for a job. Therefore, persons with the same "unemployed" labour market status could be classified into two different groups depending on the variation in their answers. Thus, the boundary between these two groups is sometimes arbitrary. However, they are similar with respect to both not working and not having wages in the data; thus, from the perspective of estimating and imputing wages for inactive and unemployed workers, it is correct to treat them as a one group (this is a standard procedure in the Heckman model, see for example, Figari 2010; 2015). Nevertheless, in the robustness checks, we take into account the difference between unemployed and inactive workers, and we exclude those who are in informal employment, since the empirical literature suggests that labour supply decisions differ between formal and informal employment.
}

(hours of work) (Table 4). Elasticities are obtained by increasing the gross hourly wage by $1 \%$ under the pre-reform tax-benefit system and estimating the changes in the participation rate and the average number of working hours after this change in policy. The results show that elasticities do not differ much between single men and single women, while the labour supply elasticity of married women is higher than that of married men.

Table 4. Hours of work and participation elasticity for singles and couples

\begin{tabular}{|c|c|c|c|c|c|c|}
\hline & \multicolumn{3}{|c|}{ Singles } & \multicolumn{3}{|c|}{ Couples } \\
\hline & Total & Females & Males & Total & Females & Males \\
\hline $\begin{array}{l}\text { Total } \\
\text { elasticity }{ }^{10}\end{array}$ & 0.525 & 0.498 & 0.541 & 0.355 & 0.487 & 0.277 \\
\hline $\begin{array}{l}\text { Participation } \\
\text { elasticity }\end{array}$ & 0.486 & 0.459 & 0.500 & 0.331 & 0.460 & 0.253 \\
\hline
\end{tabular}

There are numerous studies estimating labour supply elasticities for developed countries. The survey articles of Blundell and MaCurdy (1999) and Meghir and Phillips (2010) report that the range of estimates is very wide: values typically range between zero and 0.12 for men and between 0.05 and 2 for women. A recent paper by Bargain et al. (2013) gives the first large-scale international comparison of elasticities (for 17 European countries and the US) and finds that wage elasticities are small and vary less across the countries than previously thought. For example, the paper finds that both hours of work and participation elasticities of married women range between 0.2 and 0.6 , while for married men this range is even more compressed, between 0.05 and 0.15 . They also point out that elasticities for married women (0.2-0.6) are higher in the countries with large non-participation (such as Greece, Spain and Ireland). Elasticities for single women range between 0.1 and 0.4 , while for single men this range is further compressed, between zero and 0.3. Evidence on the labour supply behaviour in transition and post-transition countries is limited, and most deals with the early transition. For example, a recent paper by Bargain et al. (2013) finds very low male and female labour supply elasticity (0.1-0.2) in Estonia, Hungary and Poland, with the difference between coupled and single individuals being relatively small. However, the paper by Mojsoska et al. (2015) finds slightly higher elasticities in Macedonia for coupled men and women, between 0.6 and 0.8 , as well as for single men (1.0-1.1), while the estimated elasticities for single women are somewhat lower (0.2-0.3). Comparison of our results with the results from other studies indicate that the estimated values of hours of work and participation elasticities in Serbia fall within the range reported in other

\footnotetext{
${ }^{10}$ Total elasticity accounts for hours and participation elasticity
} 
countries, particularly being similar to those that experience low participations rate, like Spain, Greece and Macedonia.

According to the optimal taxation literature, IWBs can be considered as optimal transfers when labour supply elasticities are large (Brewer et al., 2010). Looking at the distribution of elasticities reveals considerable variation across the quintile groups (i.e., we find the evidence on labour supply elasticity declining with income; Figure 5). This fact is often

Figure 5. Labour supply elasticities by quintiles
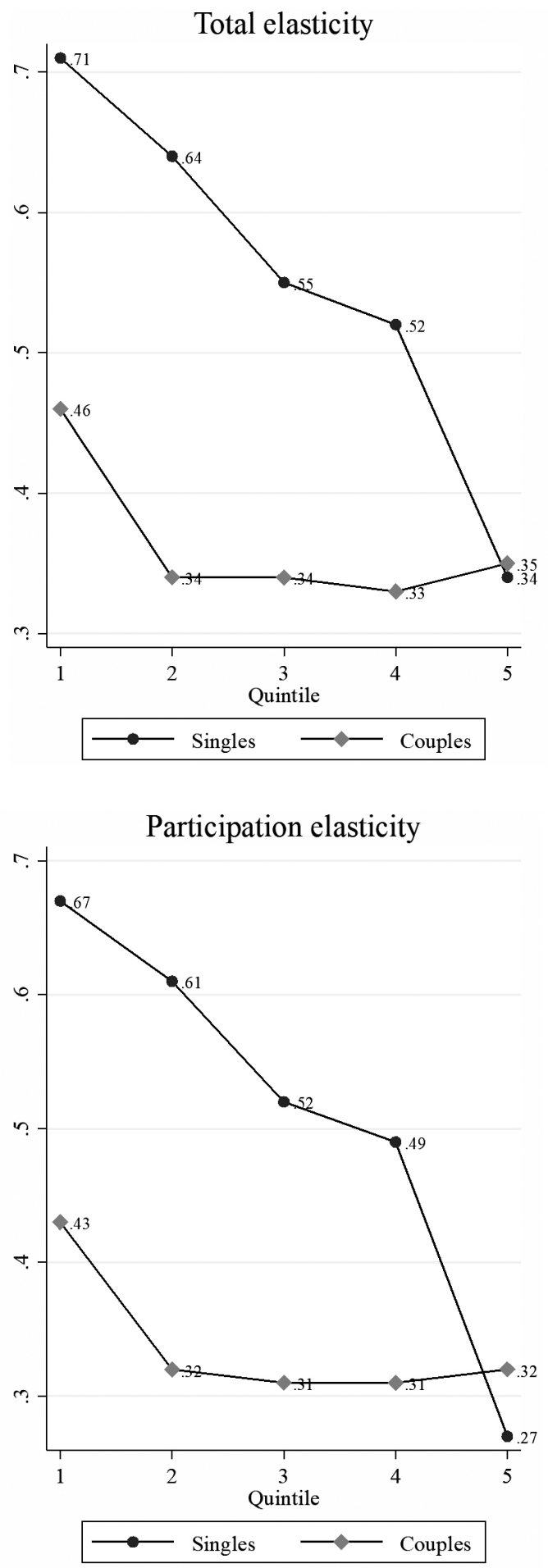

ignored in the literature, with the exception of Aaberge et al. (1999) and Roed \& Strom (2002), who point to the potential responsiveness of the individuals at the bottom of the income distribution. A pro-low-wage-earners bias in the design of the IWB schemes in our paper, together with the higher labour supply elasticities at the bottom of the income distribution, provide fertile ground for the effectiveness of IWBs in Serbia, since the conditions identified by Saez (2002) and Brewer et al. (2010) are met.

\section{Labour Supply Effects}

Starting from the estimated preferences in the utility function and the simulated changes in disposable income due to the introduction of in-work benefits, the changes in probabilities associated with different labour supply choices have been estimated (Figure 6).

Both IIWB and FIWB schemes would trigger a decline in the non-participation of single persons, with the effects being larger in the case of FIWB (non-participation would decline by 8.8 percentage points; i.e., 79,000 individuals would be activated) than in the case of IIWB (decrease in non-participation by 6.3 percentage points; i.e., equivalent to 56,000 individuals); this result is similar to the one presented in Mojsoska et al. (2015). Under both schemes, most of the activated individuals would opt for full-time employment, while only a limited number of them would switch from inactivity to part-time employment.

Although both IIWB and FIWB programs would also yield positive effects on the labour market participation of individuals in couples, the effects on the labour supply of this

Figure 6. Labour market participation choices without and with IWB (in \%) - total

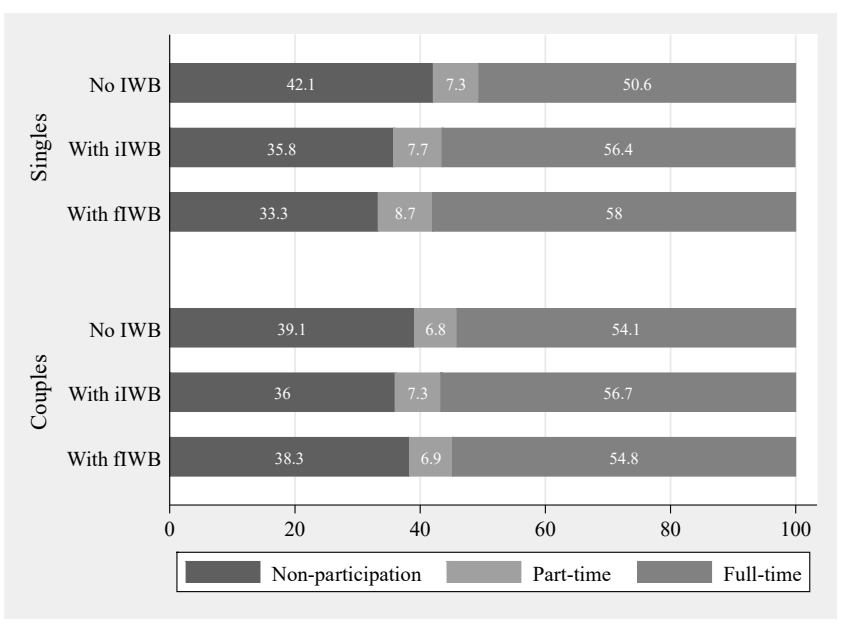

Note: Full tables of the effects are presented in the Tables A4a and A4b in the Appendix. 
subgroup would be smaller than in case of single persons, mostly due to lower labour supply elasticity. Thus, the IIWB scheme would trigger a decline in the non-participation of coupled individuals by 3.1 percentage points (approximately 41,000 individuals), while the effects of FIWB are not statistically significant (Table A4b in the Appendix). These results imply that the IIWB scheme would be more efficient in reducing non-participation of persons in couples, while the FIWB scheme would be more useful in tackling the issue of inactivity of single individuals. This may be explained by the labour supply disincentives of the FIWB for secondary earners, as is also found in other papers (Orsini \& Bargain, 2006; Haan \& Myck 2007, Myck et al. 2013).

With respect to the labour supply effects by gender, we find that FIWB would yield slightly larger effects for single women than for single men, while the effects of IIWB would be the opposite (Figure 7). On the other hand, we find no statistically significant effects of either of the two IWB programs on the labour supply of coupled individuals when analysed by gender (Table A4b, in the Appendix).

Figure 7. Labour market participation choices without and with IWB (in \%) - by gender
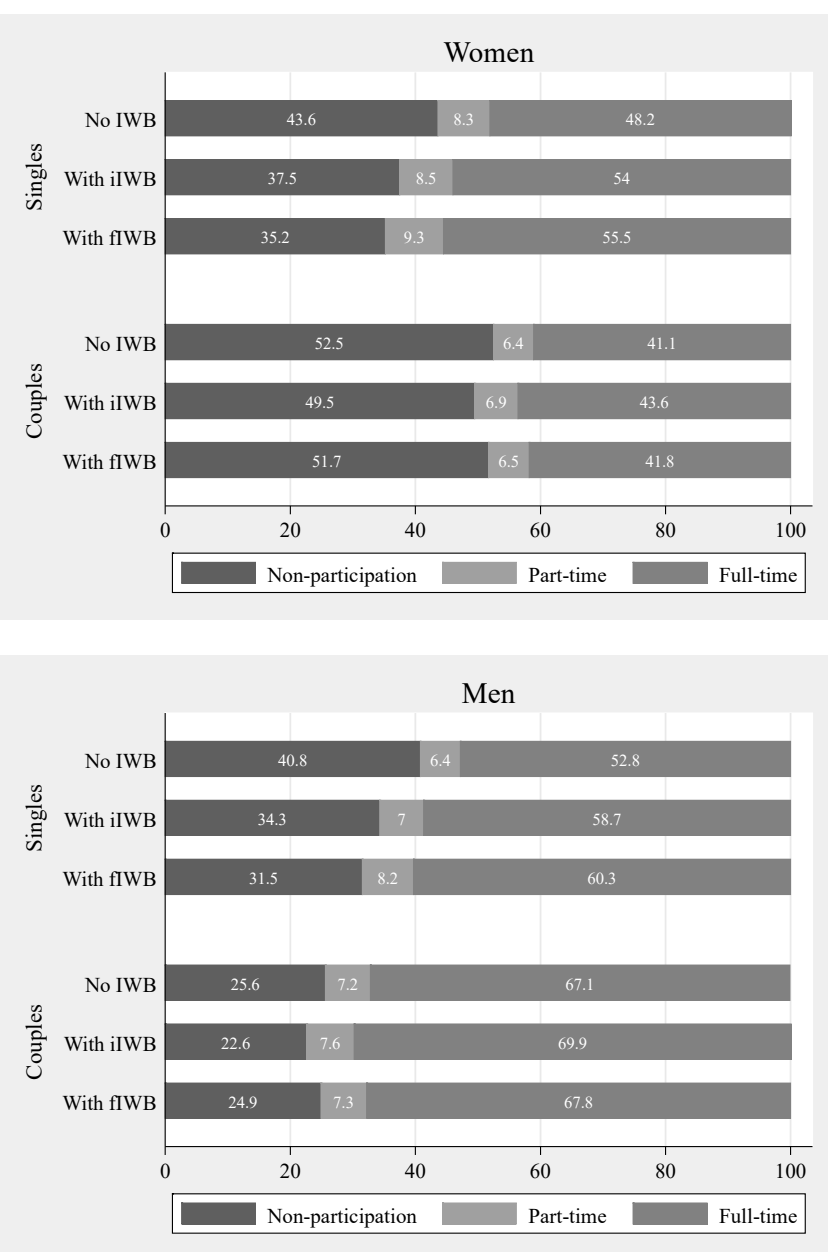

Note: Full tables of the effects are presented in the tables A4a and A4b in the Appendix.
Since the IWB schemes are also aimed at reducing poverty, the effects of hypothetical IWB schemes in Serbia are observed separately for the low-income population (those in the first quintile) and for high-income individuals (those in the fifth quintile). The results presented in Figure 8 show that both IWB schemes would considerably boost the labour market participation of people in the first quintile. Before the introduction of the IIWB, only $0.7 \%$ of single individuals from the bottom quintile have participated in the labour market. This is often the case with families with only one working household member. After the introduction of the IIWB, $18.4 \%$ of bottom-quintile single individuals would switch from non-participation to full-time employment, while $2.6 \%$ of them would opt for part-time employment. In the case of the FIWB, the labour supply effects on the bottom quintile individuals would be even larger: $22.3 \%$ would switch to full-time employment and $4.4 \%$ to parttime employment. On the other hand, neither of the two IWB schemes would have statistically significant effects on the labour supply decision of singles from the top income quintile.

Figure 8. Labour market participation without and with IWB (in \%) - the $1^{\text {st }}$ and the $5^{\text {th }}$ quintile


Note: Full tables of the effects (total and by gender) are presented in the tables A4a and A4b in the Appendix 
In the case of individuals in couples, the IIWB would boost the probability of a shift from non-participation to fulltime employment by 6.5 percentage points and to part-time employment by 0.5 percentage points, while the effects of FIWB would be significantly lower (1.6 percentage points and 0.2 percentage points, respectively). As in the case of single individuals, the labour supply effects of the FIWB and the IIWB on coupled individuals from the top quintile are not statistically significant. Large differences in terms of labour supply reaction to the IWB schemes at the bottom and the top quintile are the consequence of the design of the IWB schemes (pro-poor bias), as well of the higher labour supply elasticities at the lower end of the income distribution. The analysis of labour supply reactions by gender suggests that in the top and in the bottom quintile, a change in the non-participation rates due to the introduction of the IWB schemes, both for women and for men, would be consistent with the total effects (Tables A4a and A4b in the Appendix). The formal employment effects of the IWB schemes might be slightly larger if the formalization effects are accounted for. However, the results on the low formal-informal elasticity at extensive margin (labour force participation) may suggest these effects would be small.

Analysis of labour supply effects by income levels suggests that for both singles and couples, the IWB schemes would have larger labour supply effects in the case of low-wage earners than for those with high incomes, which implies that these schemes would be beneficial from poverty and inequality reduction perspectives as well. This is consistent with the findings in other studies (Colonna \& Marcassa, 2013; Figari, 2015), and represents an important finding for Serbia, given that the country has one of the highest Gini coefficients in Europe (Eurostat 2019b). Since the FIWB would perform better in terms of the labour supply of low income singles, while the IIWB would perform better in terms of the labour supply of low income couples, the overall effect on the change in income distribution would be almost equal under both programs. The results show that after the introduction of the IIWB, the Gini coefficient would decline from 0.386 to 0.363 , while in the case of the FIWB it would drop to 0.359 . Slight differences in equalizing effects may arise from the fact that low earners receive the full amount of the benefit under the FIWB scheme, while in the case of the IIWB, the benefit is gradually phased in, reaching the full amount only when the threshold amount of earned income is generated. On the other hand, the fact that under the FIWB, a beneficiary is receiving the full amount of benefits even when earning low income could discourage low-paid earners to increase their labour supply above the minimum level necessary to qualify for this benefit. Although the equity-efficiency trade-off is common when introducing family and individual-based IWB, our results show that such a trade-off in Serbia would not be significant, since the differences in equalizing effects of the IIWB and the FIWB would be relatively small.

\section{Conclusions}

It is often argued that high inactivity and informality rates in Serbia are the consequence of the unfavourable design of the tax-and-benefit system, under which low-paid workers accepting a formal job (especially a part-time job), tend to lose more through withdrawal of benefits and increase in labour taxes then they get compensated through wages. This is particularly true for individuals with low earnings capacity (i.e., persons with low education attainment and little or no work experience), who constitute the majority of those who are inactive or who work in the informal sector.

Tax-and-benefit policy reforms in the OECD countries in recent years have been focused on solving the twin problem of in-work poverty and persistent labour market difficulties of low-skilled individuals. Employment-conditional cash transfers to individuals facing labour market challenges have been a core element of the IWB policies for some time and are in use in more than half of the OECD countries (OECD, 2009). In the meantime, plenty of empirical studies have emerged, showing significant positive employment effects among those primarily targeted by the payment of these benefits. Although many Central and Eastern European countries have started to experiment with the IWB policies, evidence on their effects is still scarce. For Poland, for example, Myck et al. (2013) propose several reforms to the current system of in-work benefits in order to reduce negative effects of the transfer to the second earner in couples, most of them being women. The evidence on the effects of these policies in Southeastern Europe is also limited: Kosi and Bojnec (2009) for Slovenia, Mojsoska et al. (2015) for Macedonia, and Ranđelović and Žarković-Rakić (2013), Žarković-Rakić et al. (2016) and Clavet et al. (2019) for Serbia.

Results obtained in this paper suggest that both IIWB and FIWB would trigger a decline in labour market non-participation, with the effects of FIWB being larger for singles, while IIWB would have a higher impact on the labour supply of individuals in couples. At the same time, FIWB would have somewhat larger effects for single women than for men, with the effects of IIWB being the opposite, while no significant difference in terms of labour supply reaction to IIWB and FIWB by gender is found in the case of coupled individuals. With regards to the distributional aspects, we find that both IWB schemes would have a larger impact on the stimulation of the labour supply of low-income individuals than the labour supply of those at the top of the income 
distribution; this is important, since non-participation is extremely high among the low-income population. This means that IWB policies in Serbia would not only help reduce non-participation but also, to a certain degree, help reduce inequality, with net positive fiscal effects. The difference in the size of effects of IIWB and FIWB, depending on the income level and marital status, is not only the consequence of the difference in design of IIWB and FIWB policies but also the result of variation in labour supply elasticities by income levels and marital status.

The results of this paper would certainly be important for informing the policymaking process in Serbia, as the government has recently started experimenting with policies similar to the IWB schemes. Given that the labour market structure and the design of the tax-and-benefit system in Serbia are quite similar to those of neighbouring countries, we believe that the results of our analysis could also be of interest to a wider range of economies in the region.

The limitations of this paper, which also provide scope for further research, are as follows. First, this paper investigates the labour supply of IWB policy, while the labour demand analysis is beyond its scope. However, it is important to keep in mind that when there is involuntary unemployment, not all individuals who want to work are successful in finding a job. The employment effect of the IWB depends not only on the motivation of individuals to look for a job but also on the labour market capacity to accommodate them. In other words, the employment effects of IWB schemes would be also dependent on the state of the labour demand, suggesting that during times of economic prosperity there will be bigger employment gains after the introduction of the IWB than during crisis. There are studies that implicitly encompass the labour demand effects by using involuntary unemployment to describe the labour demand reaction (Bargain et al. 2010). However, use of this approach is limited to the datasets that provide the information on involuntary unemployment, which is not the case with the LSMS for Serbia in 2007. Second, the paper does not take into account general equilibrium effects. The paper by Kolm and Tonin (2011) does take such effects into account in a theoretical framework and shows how IWBs policies can be extended to larger sections of the workforce. Third, this type of analysis is inherently static; microsimulation was only used in an accounting manner (day after), and disposable income of a representative sample of the population was calculated before and after a reform using a tax-and-benefit calculator. Li and O’Donoghue (2013) provide an overview of the literature and the data requirements for the dynamic microsimulation models. Finally, although we justify in the paper why the policies simulated in SRMOD refer to the LSMS for Serbia in 2007 as the baseline year, the more recent SILC data for Serbia could be utilized, as in Žarković-Rakić et al. (2016) and Clavert et al. (2019).

\section{Acknowledgments}

This research has been generously funded by the Regional Research Promotion Program (RRPP) for the Western Balkans, supported by the University of Fribourg and the Swiss Development Agency, within the "Making work pay in the Western Balkans” project, conducted in cooperation between the Foundation for Advancement of Economics, Belgrade, Serbia and the University American College Skopje, Skopje, Macedonia.

\section{References}

Aaberge, R., Colombino, U., \& Strøm, S. (1999). Labour supply in Italy: An empirical analysis of joint household decisions, with taxes and quantityconstraints.Journal ofApplied Econometrics,14,403-422.https://doi.org/10.1002/(SICI)1099-1255(199907/08)14:4<403::AIDJAE520>3.0.CO;2-4

Arandarenko, M., \& Vukojević, V. (2008). Labor costs and labor taxes in the Western Balkans. In C. Bredenkamp, M. Gragnolati \& V. Ramljak (Eds.), Enhancing efficiency and equity: Challenges and reform opportunities facing health and pension systems in the Western Balkans (pp. 119-160). Washington, DC: The World Bank.

Arandarenko, M., Vladisavljević, M., \& Žarković-Rakić, J. (2012). From inactivity to work: analysis of the public policies impact and factors affecting inactivity. In Cerović, et al. ed.: From Global Crisis to Economic Growth. Which Way to Take? VOLUME I, ECONOMICS. Faculty of Economics, University of Belgrade.

Baldini, M., Bosi, P., \& Toso, S. (2002). Targeting welfare in Italy: Old problems and perspectives on reform. Fiscal Studies, 23(1), 51-75. https://doi.org/10.1111/j.1475-5890.2002.tb00054.x

Bargain, O., Caliendo, M., Haan, P., \& Orsini, K. (2015). 'Making work pay’ in a rationed labour market. Journal of Population Economics, 23, 323-351.

Bargain, O., Orsini, K., \& Peichl, A. (2013). Comparing labour supply elasticities in Europe and the United States: New results. Journal of Human Resources, 49(3), 723-838. https://doi.org/10.3368/jhr.49.3.723

Saget, C. (1999). The determinants of female labour supply in Hungary. Economics of Transition, 7(3), 575-591. https://doi. org/10.1111/1468-0351.00026 
Bell, K. (2005). Tackling poverty and making work pay: Can tax credits do better? Presentation given at Institute for Fiscal Studies, 15 September 2005. Retrieved from http://www.ifs.org.uk/docs/bell_taxcredits05.ppt\#5

Blundell, R. W., \& Macurdy, T. (1999). Labour supply: A review of alternative approaches. In O. Aschenfleter \& D. Card (Eds). Handbook of labour economics, edition 1, volume 3, chapter 27, pages 1559-1695. Amsterdam: Elsevier Science. https://doi.org/10.1016/S15734463(99)03008-4

Blundell, R. W., Duncan A., McCrae J., \& Meghir, C. (2000). The labour market impact of the working families tax credit. Fiscal Studies, 21(1), 75-103. https://doi.org/10.1111/j.1475-5890.2000.tb00581.x

Blundell, R., \& Hoynes, H. W. (2004). Has 'in-work' benefit reform helped the labor market? In Seeking a premier economy: The economic effects of British economic reforms, 1980-2000 (pp. 411-460). The University of Chicago Press, Chicago. https://doi.org/10.7208/ chicago/9780226092904.003.0011

Blundell, R. (2006). Earned Income Tax Credit policies: Impact and optimality. Labour Economics, 13, 423-443. https://doi.org/10.1016/j. labeco.2006.04.001

Brewer, M. (2006). Tax credits: fixed or beyond repair? In: Chote, R. et al. (Eds.), The IFS Green Budget. London: Institute for Fiscal Studies.

Brewer, M., Duncan, A., Shephard, A., \& Suarez, M. J. (2006). Did working families' tax credit work? The impact of in-work support on labour supply in Great Britain. Labour Economics, 13, 699-720. https://doi.org/10.1016/j.labeco.2005.11.002

Clavet, N.J., Tiberti, L., Vladisavljević, M., Žarković-Rakić, J., Anić, A., Krstić, G., \& Ranđelović, S. (2019). Reduction of child poverty in Serbia: Benefit or employment strategy? Economics of Transition and Institutional Change, 27, 615- 645. https://doi.org/10.1111/ ecot.12197

Colonna, F., \& Marcassa, S. (2013). Taxation and labour force participation: The case of Italy. Bank of Italy Occasional Paper No. 191. https:// doi.org/10.2139/ssrn.2303708

Davies, P. (2018) Which countries have the worst income inequality in Europe?. Euronews. Retrieved from: https://www.euronews. com/2018/04/26/which-countries-have-the-worst-income-inequality-in-europe-

De Luca, G., Rossetti, C., \& Vuri, D. (2013). In-work benefits for married couples: An ex-ante evaluation of ElTC and WTC policies in Italy. IZA Journal of Labour Policy, 3:23. https://doi.org/10.1186/2193-9004-3-23

European Commission (2010). Europe 2020: A European strategy for smart, sustainable and inclusive growth. Retrieved from: https:// ec.europa.eu/eu2020/pdf/COMPLET\%20EN\%20BARROSO\%20\%20\%20007\%20-\%20Europe\%202020\%20-\%20EN\%20version.pdf

Eissa, N., \& Hoynes, H. (1998). The Earned Income Tax Credit and the labour supply of married couples. NBER Working paper No. 6856. https://doi.org/10.3386/w6856

Eissa, N., \& Liebman J. B. (1996). Labour tax supply response to the Earned Income Tax Credit. The Quarterly Journal of Economics, 111, 605-637. https://doi.org/10.2307/2946689

Eurostat (2019a). Employment Statistics. Statistics Explained. Retrieved from: https://ec.europa.eu/eurostat/statistics-explained/index. php/Employment_statistics

Eurostat (2019b). Gini coefficient of equivalised disposable income-EU-SILC survey. Retrieved from: http://appsso.eurostat.ec.europa.eu/ nui/show.do?dataset=ilc_di12.

Figari, F. (2010). Can in-work benefits improve social inclusion in the Southern European countries? Journal of European Social Policy, 20(4), 301-315.

Figari, F. (2015). From housewives to independent earners: Can the tax system help Italian women to work? Journal of Social Policy, 44(1), 63-82. https://doi.org/10.1017/S0047279414000555

Haan, P., \& Myck, M. (2007). Apply with caution: Introducing UK-style in-work support in Germany. Fiscal Studies, 28, 43-72. https://doi. org/10.1111/j.1475-5890.2007.00047.x

Hazans, M. (2011). Informal workers across Europe: Evidence from 30 countries. IZA Discussion Paper 5871. https://doi.org/10.1596/18139450-5912

Heckman, J. (1976). The common structure of statistical models of truncation, sample selection and limited dependent variables and a simple estimator for such models. Annals of Economic and Social Measurements, 5, 475-492.

Heckman, J. (1979). Sample specification bias as a selection error. Econometrica, 47, 153-162. https://doi.org/10.2307/1912352

Immervoll, H., \& O'Donoghue, C. (2001). Welfare benefits and work incentives: An analysis of the distribution of net replacement rates in Europe using EUROMOD, a multi-country microsimulation model. EUROMOD working paper EM4/01.

Immervoll, H., \& Pearson, M. (2009). A good time for making work pay? Taking stock of in-work benefits and related measures across the OECD. IZA Policy Paper No 3.

Immervoll, H. (2012). Activation policies in OECD countries - An overview of current approaches. OECD Social Protection and Policy Note.

Koettl, J. (2010). Does formal work pay in Serbia? The role of labour taxes and social benefit design in providing disincentives for formal work. A technical note prepared for the World Bank. Working Paper. Washington, DC: World Bank.

Kolm, A. S., \& Tonin, M. (2011). In-work benefits and unemployment. International Tax and Public Finance, 18(1), 74-92. https://doi. org/10.1007/s10797-010-9148-6

Krstić, G., \& Sanfey, P. (2011). Earnings inequality and informal economy: Evidence from Serbia. Economics of Transition, 19(1), $179-199$. https://doi.org/10.1111/j.1468-0351.2010.00400.x

Krstić, G., Arandarenko, M., Arsić, M., Radulović, B., Ranđelović, S., \& Janković, I. (2015). Formalising the shadow economy in Serbia: Main findings and recommendations. In G. Krstić \& F. Schneider (Eds.), Formalising the shadow economy in Serbia (pp. 123-158). Springer Open, New York. https://doi.org/10.1007/978-3-319-13437-6_9 
Leibfritz, W. (2008). Increasing employment in FYR Macedonia: The role of labour taxation. A Policy Note prepared for the World Bank. Leppik, L. (2006). In-work benefits: Literature review. Tallin: PRAXIS Center for Policy Studies.

Li, J., \& O'Donoghue, C. (2013). A survey of dynamic microsimulation models: Uses, model structure and methodology. International Journal of Microsimulation, 6(2), 3-55.

Löfller, M., Peichl, A., \& Siegloch, S. (2014). Structural labour supply models and wage exogeneity. IZA Discussion Paper No. 8281. https:// doi.org/10.2139/ssrn.2464472

McFadden, D. (1974). Conditional logit analysis of qualitative choice behaviour. In P. Zarembka (Ed.), Frontiers in econometrics (pp. 105-142). New York, NY: Academic Press.

Meghir, C., \& Phillips, D. (2010). Labour supply and taxes. In J. Mirrlees (Ed.), The Mirrlees review. (pp. 202-274). Oxford: Oxford University Press.

Meyer, B., \&Rosenbaum, D. (2000). Making single mothers work: Recent tax and welfare policy and its effects. National Tax Journal, 53(4), 1027-1062. https://doi.org/10.17310/ntj.2000.4S1.02

Mojsoska-Blazevski, N. (2012). Taxation of labour: The effect of labour taxes and costs on employment in Macedonia. Post-Communist Economies, 24(2), 241-256. https://doi.org/10.1080/14631377.2012.675158

Mojsoska-Blazevski N., Petreski, M., \&Petreska, D. (2015). Increasing the labour market activity of the poor, females, and informal workers: Let's make work pay in Macedonia. Eastern European Economics, 53(6), 466-490. https://doi.org/10.1080/00128775.2015. 1103656

Myck, M., Kurowska, A., \& Kundera, M. (2013). Financial support for families with children and its trade-offs: Balancing redistribution and parental work incentives. Baltic Journal of Economics, 13(2), 61-85. https://doi.org/10.1080/1406099X.2013.10840533

OECD (2009). A good time for making work pay? Taking stock of in-work benefits and related measures across the OECD. OECD Working Papers No. 81.

OECD (2019). Labour force participation rate. Retrieved from: https://data.oecd.org/emp/labour-force-participation-rate.htm.

Orsini, K. (2006). Is Belgium making work pay? KU Leuven Working Paper. https://doi.org/10.2139/ssrn.934317

Orsini, K., \& Bargain, O. (2006). In-work policies in Europe: Killing two birds with one stone? Labour Economics, 13(6), 667-693. https:// doi.org/10.1016/j.labeco.2005.10.007

Owens, J. (2006). Fundamental tax reform: An international perspective. National Tax Journal, 59(1), 131-64. https://doi.org/10.17310/ ntj.2006.1.06

Ranđelović, S., \& Žarković-Rakić, J. (2013). Improving working incentives: Evaluation of tax policy reform using SRMOD. International Journal of Microsimulation, 6(1), 157-176.

St Martin, A., \& Whiteford, P. (2003). More jobs and better pay. OECD Observer No. 239, September 2003. Retrieved from http://oecdobserver.org/news/archivestory.php/aid/1077/More_jobs_and_better_pay.html

Saez, E. (2002). Optimal income transfer programs: Intensive versus extensive labour supply responses. The Quarterly Journal of Economics, 117.1039-73. https://doi.org/10.1162/003355302760193959

Scholtz, J. K. (1994). The Earned Income Tax Credit: Participation, compliance, and anti-poverty effectiveness. National Tax Journal, 47, $59-81$.

Scholtz, J. K. (1996). In-work benefits in the United States: The Earned Income Tax Credit. Economic Journal, 106, 156-69. https://doi. org/10.2307/2234939

SORS (Statistical Office of the Republic of Serbia) (2016). Labour Force Survey in the Republic of Serbia, 2015, Bulletin 608, Belgrade: SORS.

Sutherland, H., \& Figari, F. (2013). EUROMOD: the European Union tax-benefit microsimulation model. International Journal of Microsimulation, 6(1), 4-26.

Van Soest, A. (1995). Structural models of family labour supply: A discrete choice approach. Journal of Human Resources, 30, 63-88. https://doi.org/10.2307/146191

Žarković-Rakić, J., Ranđelović, S., \& Vladisavljević, M. (2016). Labour market effects of Social Security contributions reform in Serbia. Economic Annals, 208, 73-92. https://doi.org/10.2298/EKA1608073Z 


\section{APPENDIX}

Table A1. Descriptive statistics for the labour supply estimation

\begin{tabular}{|c|c|c|c|c|}
\hline & mean & std. dev. & $\min$ & $\max$ \\
\hline Secondary education & 0.604 & 0.489 & 0 & 1 \\
\hline Tertiary education & 0.154 & 0.361 & 0 & 1 \\
\hline Working experience & 13.171 & 11.867 & 0 & 48 \\
\hline Settlement (Urban==1) & 0.575 & 0.494 & 0 & 1 \\
\hline Region Vojvodina & 0.257 & 0.437 & 0 & 1 \\
\hline Region West Serbia & 0.306 & 0.461 & 0 & 1 \\
\hline Region East Serbia & 0.262 & 0.440 & 0 & 1 \\
\hline Children under 3 years & 0.125 & 0.373 & 0 & 3 \\
\hline Single & 0.330 & 0.470 & 0 & 1 \\
\hline Age & 40.359 & 11.917 & 18 & 64 \\
\hline Non-work hh income per adult equivalent (in 1.000 RSD) & 3.332 & 5.537 & 0 & 75.80175 \\
\hline Total sample & 6,473 & & & \\
\hline
\end{tabular}

Table A2. Wage equation for females and males, with Heckman correction

\begin{tabular}{|c|c|c|c|c|}
\hline & \multicolumn{2}{|c|}{ Females } & \multicolumn{2}{|c|}{ Males } \\
\hline & Coef. & Std. Err. & Coef. & Std. Err. \\
\hline \multicolumn{5}{|l|}{ Hourly wage rate (ln) } \\
\hline Primary education (omitted) & - & & - & \\
\hline Secondary education & $0.348^{* * *}$ & $(0.040)$ & $0.207^{* * *}$ & $(0.035)$ \\
\hline Tertiary education & $0.894^{* * *}$ & $(0.049)$ & $0.698^{* * *}$ & $(0.045)$ \\
\hline Working experience & $0.009^{* * *}$ & $(0.002)$ & $0.003^{* * *}$ & $(0.001)$ \\
\hline Settlement (Urban==1) & $0.185^{* * *}$ & $(0.027)$ & $0.178^{* * *}$ & $(0.025)$ \\
\hline Region Belgrade (omitted) & - & & - & \\
\hline Region Vojvodina & $-0.192^{* * *}$ & $(0.037)$ & $-0.195^{* * *}$ & $(0.039)$ \\
\hline Region West Serbia & $-0.291^{* * *}$ & $(0.036)$ & $-0.226^{* * *}$ & $(0.036)$ \\
\hline Region East Serbia & $-0.348^{* * *}$ & $(0.038)$ & $-0.312^{* * *}$ & $(0.039)$ \\
\hline Constant & $4.341^{* * *}$ & $(0.071)$ & $4.708^{* * *}$ & $(0.058)$ \\
\hline \multicolumn{5}{|c|}{ Employment (1 = in employment) } \\
\hline Primary education (omitted) & - & & - & \\
\hline Secondary education & $0.323^{* * *}$ & $(0.070)$ & $0.188^{* * *}$ & $(0.073)$ \\
\hline Tertiary education & $0.909^{* * *}$ & $(0.089)$ & $0.812^{* * *}$ & $(0.108)$ \\
\hline Working experience & $0.096^{* * *}$ & $(0.006)$ & $0.097^{* * *}$ & $(0.007)$ \\
\hline Settlement (Urban==1) & 0.021 & $(0.054)$ & $-0.246^{* * *}$ & $(0.058)$ \\
\hline$\underline{\text { Region Belgrade (omitted) }}$ & - & & - & \\
\hline Region Vojvodina & $-0.145^{*}$ & $(0.081)$ & -0.030 & $(0.091)$ \\
\hline Region West Serbia & -0.081 & $(0.077)$ & -0.040 & $(0.086)$ \\
\hline Region East Serbia & -0.120 & $(0.079)$ & -0.035 & $(0.090)$ \\
\hline Children under 3yoa & $-0.528^{* * *}$ & $(0.078)$ & 0.043 & $(0.076)$ \\
\hline Single & $0.251^{* * *}$ & $(0.063)$ & $-0.130^{*}$ & $(0.071)$ \\
\hline Age & $0.173^{* * *}$ & $(0.021)$ & $0.202^{* * *}$ & $(0.017)$ \\
\hline
\end{tabular}


Saša Ranđelović, Jelena Žarković Rakić, Marko Vladisavljević, Sunčica Vujić: Labour Supply and Inequality Effects of In-Work Benefits: Evidence from Serbia

Table A2. Wage equation for females and males, with Heckman correction (continued)

\begin{tabular}{|c|c|c|c|c|}
\hline & \multicolumn{2}{|c|}{ Females } & \multicolumn{2}{|c|}{ Males } \\
\hline & Coef. & Std. Err. & Coef. & Std. Err. \\
\hline Age squared & $-0.003^{* * *}$ & $(0.000)$ & $-0.004^{* * *}$ & $(0.000)$ \\
\hline Non-work hh income per adult eq. (in 1.000 RSD) & $-0.016^{* * *}$ & $(0.005)$ & $-0.028^{* * *}$ & $(0.005)$ \\
\hline Constant & $-2.980^{* * *}$ & $(0.380)$ & $-2.661^{* * *}$ & $(0.344)$ \\
\hline Rho & 0.33 & $(0.087)$ & -0.0049 & $(0.090)$ \\
\hline Lambda & 0.19 & $(0.046)$ & -0.0025 & $(0.050)$ \\
\hline$\underline{\text { Sigma }}$ & 0.57 & $(0.021)$ & 0.51 & $(0.023)$ \\
\hline Observations & 3,430 & & 3,043 & \\
\hline Censored N & 1733 & & 802 & \\
\hline Wald test: joint significance [Chi2 (5)] & 549.61 & & 506.93 & \\
\hline Prob > Chi2 & 0.000 & & 0.000 & \\
\hline LR test of indep. eqns. $($ rho $=0)$ : & 15.7 & & 0.0030 & \\
\hline Prob > chi2: & 0.000 & & 0.96 & \\
\hline
\end{tabular}

Table A3a. Preference estimates for singles (Conditional Logit)

\begin{tabular}{|c|c|c|c|c|c|c|}
\hline & \multicolumn{2}{|c|}{ Total } & \multicolumn{2}{|c|}{ Females } & \multicolumn{2}{|c|}{ Males } \\
\hline & Coef. & Std. Err. & Coef. & Std. Err. & Coef. & Std. Err. \\
\hline Income & $5.186^{* * *}$ & $(0.715)$ & $5.145^{* * *}$ & $(0.966)$ & $5.477^{* * *}$ & $(1.174)$ \\
\hline${ }^{*}$ Age & $-0.221^{* * *}$ & $(0.038)$ & $-0.211^{* * *}$ & $(0.055)$ & $-0.248^{* * *}$ & $(0.061)$ \\
\hline${ }^{*}$ Age square (/100) & $0.270^{* * *}$ & $(0.047)$ & $0.271^{* * *}$ & $(0.073)$ & $0.298^{* * *}$ & $(0.074)$ \\
\hline${ }^{*}$ Secondary ed.(a) & $-0.522^{* * *}$ & $(0.156)$ & $-0.802^{* * *}$ & $(0.259)$ & -0.254 & $(0.247)$ \\
\hline *Tertiary ed. & $-0.461^{* * *}$ & $(0.130)$ & $-0.751^{* *}$ & $(0.382)$ & -0.035 & $(0.280)$ \\
\hline${ }^{*}$ Children ${ }^{\cdot(b)}$ & 0.112 & $(0.199)$ & -0.049 & $(0.241)$ & 0.431 & $(0.467)$ \\
\hline Square & $-0.017^{* * *}$ & $(0.002)$ & $-0.021^{* * *}$ & $(0.004)$ & $-0.024^{* * *}$ & $(0.009)$ \\
\hline Income* Hours of work & $0.002^{*}$ & $(0.001)$ & 0.002 & $(0.001)$ & 0.003 & $(0.002)$ \\
\hline Hours of work & $-0.532^{* * *}$ & $(0.029)$ & $-0.540^{* * *}$ & $(0.039)$ & $-0.529^{* * *}$ & $(0.048)$ \\
\hline${ }^{*}$ Age & $0.017^{* * *}$ & $(0.002)$ & $0.016^{* * *}$ & $(0.002)$ & $0.019^{* * *}$ & $(0.003)$ \\
\hline${ }^{*}$ Age square $(/ 100)$ & $-0.022^{* * *}$ & $(0.002)$ & $-0.021^{* * *}$ & $(0.003)$ & $-0.024^{* * *}$ & $(0.003)$ \\
\hline${ }^{*}$ Secondary ed. (a) & $0.027^{* * *}$ & $(0.006)$ & $0.037^{* * *}$ & $(0.010)$ & 0.015 & $(0.010)$ \\
\hline *Tertiary ed. & $0.021^{* * *}$ & $(0.007)$ & 0.021 & $(0.021)$ & 0.008 & $(0.017)$ \\
\hline${ }^{*}$ Children ${ }^{(b)}$ & -0.003 & $(0.022)$ & 0.017 & $(0.030)$ & -0.048 & $(0.039)$ \\
\hline Square & $0.005^{* * *}$ & $(0.000)$ & $0.005^{* * *}$ & $(0.000)$ & $0.004^{* * *}$ & $(0.000)$ \\
\hline Fixed costs & - & & - & & - & \\
\hline${ }^{*}$ Children & -0.578 & $(0.758)$ & -0.586 & $(1.115)$ & -0.187 & $(1.130)$ \\
\hline$N(c)$ & 1,992 & & 3,231 & & 2,745 & \\
\hline Pseudo R Square & 0.303 & & 0.312 & & 0.312 & \\
\hline Log-likelihood & -1525 & & -814.6 & & -691.1 & \\
\hline Wald test: joint sig [Chi2 (16)] & 1327.35 & & 628.13 & & 737.24 & \\
\hline Prob > Chi2 & 0.000 & & 0.000 & & 0.000 & \\
\hline
\end{tabular}

Notes:

(a)Primary education omitted

.(b) Dummy variable for single family with child

.(c) Estimated on the total of 5,976 observations = number of singles in the sample $(1,992)$ multiplied by number of choices in simulation (3) 
Table A3b. Preference estimates for couples (Conditional logit)

\begin{tabular}{|c|c|c|c|c|c|c|}
\hline & \multicolumn{2}{|c|}{ Total } & \multicolumn{2}{|c|}{ Female } & \multicolumn{2}{|c|}{ Male } \\
\hline & Coef. & Std. Err. & Coef. & Std. Err. & Coef. & Std. Err. \\
\hline Income & -0.358 & $(0.665)$ & & & & \\
\hline *Age & & & 0.045 & $(0.034)$ & -0.040 & $(0.035)$ \\
\hline${ }^{*}$ Age square (/100) & & & -0.041 & $(0.040)$ & 0.059 & $(0.040)$ \\
\hline *Secondary ed.(a) & & & $-0.120^{*}$ & $(0.069)$ & $-0.120^{*}$ & $(0.069)$ \\
\hline *Tertiary ed. & & & -0.057 & $(0.095)$ & -0.057 & $(0.095)$ \\
\hline${ }^{*}$ Children ${ }^{(b)}$ & $0.452^{* * *}$ & $(0.112)$ & & & & \\
\hline Square & $-0.004^{* * *}$ & $(0.001)$ & & & & \\
\hline Income * Hours of work & & & 0.001 & $(0.000)$ & 0.000 & $(0.001)$ \\
\hline Hours of work & & & $-0.388^{* * *}$ & $(0.038)$ & $-0.286^{* * *}$ & $(0.040)$ \\
\hline *Age & & & $0.009^{* * *}$ & $(0.002)$ & $0.009^{* * *}$ & $(0.002)$ \\
\hline${ }^{*}$ Age square $(/ 100)$ & & & $-0.013^{* * *}$ & $(0.002)$ & $-0.013^{* * *}$ & $(0.002)$ \\
\hline${ }^{*}$ Secondary ed. ${ }^{(a)}$ & & & $0.028^{* * *}$ & $(0.005)$ & -0.007 & $(0.005)$ \\
\hline${ }^{*}$ Tertiary ed. & & & $0.039^{* * *}$ & $(0.009)$ & $-0.021^{* *}$ & $(0.009)$ \\
\hline${ }^{*}$ Children ${ }^{(b)}$ & & & $-0.037^{* * *}$ & $(0.006)$ & $-0.021^{* * *}$ & $(0.006)$ \\
\hline $\begin{array}{l}\text { * Female and male hours } \\
\text { Interaction (/100) }\end{array}$ & $0.033^{* * *}$ & $(0.010)$ & & & & \\
\hline Square & & & $0.005^{* * *}$ & $(0.000)$ & $0.004^{* * *}$ & $(0.000)$ \\
\hline Fixed costs & & & - & & - & \\
\hline${ }^{*}$ Children & & & -0.043 & $(0.247)$ & 0.194 & $(0.213)$ \\
\hline$N^{(c)}$ & 1,543 & & & & & \\
\hline Pseudo R Square & 0.346 & & & & & \\
\hline Log-likelihood & -2218 & & & & & \\
\hline $\begin{array}{l}\text { Wald test: joint sig. } \\
\text { [Chi2 (30)] }\end{array}$ & 2343.89 & & & & & \\
\hline Prob $>$ Chi2 & 0.000 & & & & & \\
\hline
\end{tabular}

Notes:

(a)Primary education omitted

.(b) Dummy variable for single family with child

(c) Estimated on the total of 13,887 observations = number of couples in the sample $(1,543)$ multiplied by number of choices $(9)$

Table A4a. Effects of the reforms for singles - percentages and number of people for each choice, total, first and fifth quintile

\begin{tabular}{cccccccccccc} 
& & \multicolumn{3}{c}{ Share of the choices } & \multicolumn{2}{c}{ Change (in pp) } & \multicolumn{2}{c}{ Number of people per choice } & Change \\
\hline & & no IWB & with ilWB & with fIWB & ilWB & fIWB & no IWB & ilWB & fIWB & ilWB & fIWB \\
\hline Total & Non-participation & $42.1 \%$ & $35.8 \%$ & $33.3 \%$ & $-6.3^{* *}$ & $-8.8^{* *}$ & 377,842 & 321,568 & 298,738 & $-56,274$ & $-79,104$ \\
\hline \multirow{2}{*}{} & Part-time & $7.3 \%$ & $7.7 \%$ & $8.7 \%$ & 0.4 & 1.4 & 65,666 & 69,464 & 78,144 & 3,798 & 12,478 \\
\hline & Full-time & $50.6 \%$ & $56.4 \%$ & $58.0 \%$ & $5.9^{* *}$ & $7.4^{* *}$ & 453,553 & 506,029 & 520,179 & 52,476 & 66,626 \\
\hline Female & Non-participation & $43.6 \%$ & $37.5 \%$ & $35.2 \%$ & $-6.0^{* *}$ & $-8.3^{* *}$ & 187,292 & 161,362 & 151,411 & $-25,930$ & $-35,881$ \\
\hline & Part-time & $8.3 \%$ & $8.5 \%$ & $9.3 \%$ & 0.2 & 1.0 & 35,632 & 36,565 & 39,987 & 933 & 4,355 \\
\hline & Full-time & $48.2 \%$ & $54.0 \%$ & $55.5 \%$ & $5.8^{*}$ & $7.3^{* *}$ & 207,116 & 232,113 & 238,641 & 24,997 & 31,526 \\
\hline Male & Non-participation & $40.8 \%$ & $34.3 \%$ & $31.5 \%$ & $-6.5^{* *}$ & $-9.3^{* *}$ & 190,550 & 160,206 & 147,327 & $-30,344$ & $-43,223$ \\
\hline & Part-time & $6.4 \%$ & $7.0 \%$ & $8.2 \%$ & 0.6 & 1.7 & 30,034 & 32,899 & 38,157 & 2,865 & 8,123 \\
\hline & Full-time & $52.8 \%$ & $58.7 \%$ & $60.3 \%$ & $5.9^{* *}$ & $7.5^{* *}$ & 246,438 & 273,917 & 281,538 & 27,479 & 35,100 \\
\hline
\end{tabular}


Saša Ranđelović, Jelena Žarković Rakić, Marko Vladisavljević, Sunčica Vujić: Labour Supply and Inequality Effects of In-Work Benefits: Evidence from Serbia

Table A4a. Effects of the reforms for singles - percentages and number of people for each choice, total, first and fifth quintile (continued)

\begin{tabular}{|c|c|c|c|c|c|c|c|c|c|c|c|}
\hline & & \multicolumn{3}{|c|}{ Share of the choices } & \multicolumn{2}{|c|}{ Change (in pp) } & \multicolumn{3}{|c|}{ Number of people per choice } & \multicolumn{2}{|c|}{ Change } \\
\hline & & no IWB & with ilWB & with fIWB & ilWB & fIWB & no IWB & ilWB & fIWB & ilWB & fIWB \\
\hline & \multicolumn{11}{|c|}{ The $1^{\text {st }}$ quintile } \\
\hline \multirow[t]{3}{*}{ Total } & Non-participation & $99.3 \%$ & $79.0 \%$ & $73.3 \%$ & $-20.2^{* *}$ & $-26.0^{* *}$ & 178,094 & 141,809 & 131,487 & $-36,286$ & $-46,607$ \\
\hline & Part-time & $0.6 \%$ & $2.6 \%$ & $4.4 \%$ & 2.0 & 3.9 & 1,019 & 4,618 & 7,950 & 3,599 & 6,931 \\
\hline & Full-time & $0.2 \%$ & $18.4 \%$ & $22.3 \%$ & $18.2^{* *}$ & $22.1^{* *}$ & 319 & 33,006 & 39,995 & 32,686 & 39,676 \\
\hline \multirow[t]{3}{*}{ Female } & Non-participation & $98.8 \%$ & $79.2 \%$ & $74.3 \%$ & $-19.6^{* *}$ & $-24.5^{* *}$ & 83,379 & 66,842 & 62,673 & $-16,538$ & $-20,706$ \\
\hline & Part-time & $1.2 \%$ & $3.1 \%$ & $4.4 \%$ & 1.9 & 3.2 & 1,019 & 2,625 & 3,680 & 1,605 & 2,661 \\
\hline & Full-time & $0.0 \%$ & $17.7 \%$ & $21.4 \%$ & $17.7^{* *}$ & $21.4^{* *}$ & 0 & 14,932 & 18,045 & 14,932 & 18,045 \\
\hline \multirow[t]{4}{*}{ Male } & Non-participation & $99.7 \%$ & $78.9 \%$ & $72.4 \%$ & $-20.8^{* *}$ & $-27.3^{* *}$ & 94,715 & 74,967 & 68,814 & $-19,748$ & $-25,901$ \\
\hline & Part-time & $0.0 \%$ & $2.1 \%$ & $4.5 \%$ & 2.1 & 4.5 & 0 & 1,994 & 4,270 & 1,994 & 4,270 \\
\hline & Full-time & $0.3 \%$ & $19.0 \%$ & $23.1 \%$ & $18.7^{* *}$ & $22.8^{* *}$ & 319 & 18,073 & 21,950 & 17,754 & 21,631 \\
\hline & \multicolumn{11}{|c|}{ The $5^{\text {th }}$ quintile } \\
\hline \multirow[t]{3}{*}{ Total } & Non-participation & $14.7 \%$ & $16.2 \%$ & $14.6 \%$ & 1.5 & -0.1 & 26,254 & 28,882 & 26,048 & 2,628 & -206 \\
\hline & Part-time & $9.0 \%$ & $8.8 \%$ & $9.4 \%$ & -0.2 & 0.4 & 16,026 & 15,736 & 16,812 & -290 & 786 \\
\hline & Full-time & $76.4 \%$ & $75.0 \%$ & $76.0 \%$ & -1.3 & -0.3 & 136,522 & 134,184 & 135,942 & $-2,338$ & -580 \\
\hline \multirow[t]{3}{*}{ Female } & Non-participation & $16.3 \%$ & $18.6 \%$ & $16.5 \%$ & 2.4 & 0.2 & 15,380 & 17,626 & 15,597 & 2,246 & 217 \\
\hline & Part-time & $11.2 \%$ & $11.0 \%$ & $11.8 \%$ & -0.3 & 0.5 & 10,635 & 10,379 & 11,153 & -256 & 518 \\
\hline & Full-time & $72.5 \%$ & $70.4 \%$ & $71.7 \%$ & -2.1 & -0.8 & 68,585 & 66,595 & 67,850 & $-1,989$ & -735 \\
\hline \multirow[t]{3}{*}{ Male } & Non-participation & $12.9 \%$ & $13.4 \%$ & $12.4 \%$ & 0.5 & -0.5 & 10,874 & 11,256 & 10,451 & 382 & -423 \\
\hline & Part-time & $6.4 \%$ & $6.4 \%$ & $6.7 \%$ & 0.0 & 0.3 & 5,390 & 5,357 & 5,659 & -33 & 268 \\
\hline & Full-time & $80.7 \%$ & $80.3 \%$ & $80.9 \%$ & -0.4 & 0.2 & 67,937 & 67,589 & 68,092 & -349 & 155 \\
\hline
\end{tabular}

Notes: Stars in the table denote significant effects $(* \mathrm{p}<0.1 ; * * \mathrm{p}<0.05)$; t-tests available upon the request. Data weighted by the weights provided by RSO.

Table A4b. Effects of the reforms for couples - percentages and number of people for each choice, total, first and fifth quintiles

\begin{tabular}{|c|c|c|c|c|c|c|c|c|c|c|c|}
\hline & & \multicolumn{3}{|c|}{ Share of the choices } & \multicolumn{2}{|c|}{ Change (in pp) } & \multicolumn{3}{|c|}{ Number of people per choice } & \multicolumn{2}{|c|}{ Change } \\
\hline & & no IWB & with ilWB & with fIWB & ilWB & fIWB & no IWB & ilWB & fIWB & ilWB & fIWB \\
\hline \multirow[t]{3}{*}{ Total } & Non-participation & $39.1 \%$ & $36.0 \%$ & $38.3 \%$ & $-3.1^{*}$ & -0.8 & 525,866 & 484,883 & 515,241 & $-40,983$ & $-10,625$ \\
\hline & Part-time & $6.8 \%$ & $7.3 \%$ & $6.9 \%$ & 0.4 & 0.1 & 91,751 & 97,687 & 92,754 & 5,935 & 1,003 \\
\hline & Full-time & $54.1 \%$ & $56.7 \%$ & $-54.8 \%$ & $2.7^{*}$ & 0.7 & 728,540 & 763,588 & 738,163 & 35,048 & 9,623 \\
\hline \multirow[t]{3}{*}{ Female } & Non-participation & $52.5 \%$ & $49.5 \%$ & $51.7 \%$ & -3.0 & -0.9 & 353,486 & 332,986 & 347,645 & $-20,500$ & $-5,841$ \\
\hline & Part-time & $6.4 \%$ & $6.9 \%$ & $6.5 \%$ & 0.6 & 0.1 & 43,016 & 46,762 & 43,848 & 3,746 & 832 \\
\hline & Full-time & $41.1 \%$ & $43.6 \%$ & $41.8 \%$ & 2.5 & 0.7 & 276,577 & 293,331 & 281,585 & 16,754 & 5,009 \\
\hline \multirow[t]{4}{*}{ Male } & Non-participation & $25.6 \%$ & $22.6 \%$ & $24.9 \%$ & -3.0 & -0.7 & 172,380 & 151,897 & 167,596 & $-20,483$ & $-4,784$ \\
\hline & Part-time & $7.2 \%$ & $7.6 \%$ & $7.3 \%$ & 0.3 & 0.0 & 48,735 & 50,925 & 48,906 & 2,190 & 170 \\
\hline & Full-time & $67.1 \%$ & $69.9 \%$ & $67.8 \%$ & 2.7 & 0.7 & 451,964 & 470,257 & 456,578 & 18,294 & 4,614 \\
\hline & \multicolumn{11}{|c|}{ The $1^{\text {st }}$ quintile } \\
\hline \multirow[t]{3}{*}{ Total } & Non-participation & $83.9 \%$ & $76.9 \%$ & $82.1 \%$ & $-6.9^{* *}$ & -1.8 & 228,222 & 209,333 & 223,433 & $-18,889$ & $-4,789$ \\
\hline & Part-time & $4.5 \%$ & $5.0 \%$ & $4.7 \%$ & 0.4 & 0.1 & 12,348 & 13,487 & 12,724 & 1,139 & 376 \\
\hline & Full-time & $11.6 \%$ & $18.1 \%$ & $13.2 \%$ & $6.5^{* *}$ & 1.6 & 31,605 & 49,355 & 36,018 & 17,750 & 4,413 \\
\hline \multirow[t]{3}{*}{ Female } & Non-participation & $94.0 \%$ & $88.4 \%$ & $92.3 \%$ & $-5.6^{*}$ & -1.7 & 127,927 & 120,307 & 125,556 & $-7,620$ & $-2,370$ \\
\hline & Part-time & $1.2 \%$ & $1.9 \%$ & $1.5 \%$ & 0.7 & 0.2 & 1,644 & 2,622 & 1,977 & 978 & 333 \\
\hline & Full-time & $4.8 \%$ & $9.7 \%$ & $6.3 \%$ & 4.9 & 1.5 & 6,516 & 13,158 & 8,554 & 6,642 & 2,037 \\
\hline
\end{tabular}


Table A4b. Effects of the reforms for couples - percentages and number of people for each choice, total, first and fifth quintiles (continued)

\begin{tabular}{|c|c|c|c|c|c|c|c|c|c|c|c|}
\hline & & \multicolumn{3}{|c|}{ Share of the choices } & \multicolumn{2}{|c|}{ Change (in pp) } & \multicolumn{3}{|c|}{ Number of people per choice } & \multicolumn{2}{|c|}{ Change } \\
\hline & & no IWB & with ilWB & with fIWB & ilWB & fIWB & no IWB & ilWB & fIWB & ilWB & fIWB \\
\hline \multirow[t]{4}{*}{ Male } & Non-participation & $73.7 \%$ & $65.4 \%$ & $71.9 \%$ & $-8.3^{*}$ & -1.8 & 100,295 & 89,026 & 97,876 & $-11,270$ & $-2,419$ \\
\hline & Part-time & $7.9 \%$ & $8.0 \%$ & $7.9 \%$ & 0.1 & 0.0 & 10,704 & 10,865 & 10,747 & 161 & 43 \\
\hline & Full-time & $18.4 \%$ & $26.6 \%$ & $20.2 \%$ & 8.2 & 1.7 & 25,088 & 36,197 & 27,464 & 11,108 & 2,376 \\
\hline & \multicolumn{11}{|c|}{ The $5^{\text {th }}$ quintile } \\
\hline \multirow[t]{3}{*}{ Total } & Non-participation & $10.3 \%$ & $9.5 \%$ & $10.2 \%$ & -0.7 & -0.1 & 27,582 & 25,642 & 27,392 & $-1,940$ & -190 \\
\hline & Part-time & $8.4 \%$ & $9.0 \%$ & $8.5 \%$ & 0.5 & 0.0 & 22,687 & 24,118 & 22,739 & 1,431 & 52 \\
\hline & Full-time & $81.3 \%$ & $81.5 \%$ & $81.4 \%$ & 0.2 & 0.1 & 218,571 & 219,081 & 218,710 & 510 & 139 \\
\hline \multirow[t]{3}{*}{ Female } & Non-participation & $16.1 \%$ & $15.0 \%$ & $16.0 \%$ & -1.1 & -0.1 & 21,591 & 20,123 & 21,452 & $-1,469$ & -139 \\
\hline & Part-time & $10.5 \%$ & $11.0 \%$ & $10.5 \%$ & 0.6 & 0.0 & 14,051 & 14,833 & 14,070 & 782 & 19 \\
\hline & Full-time & $73.5 \%$ & $74.0 \%$ & $73.6 \%$ & 0.5 & 0.1 & 98,777 & 99,464 & 98,898 & 687 & 121 \\
\hline \multirow[t]{3}{*}{ Male } & Non-participation & $4.5 \%$ & $4.1 \%$ & $4.4 \%$ & -0.4 & 0.0 & 5,991 & 5,519 & 5,940 & -472 & -51 \\
\hline & Part-time & $6.4 \%$ & $6.9 \%$ & $6.4 \%$ & 0.5 & 0.0 & 8,636 & 9,285 & 8,669 & 649 & 33 \\
\hline & Full-time & $89.1 \%$ & $89.0 \%$ & $89.1 \%$ & -0.1 & 0.0 & 119,794 & 119,616 & 119,812 & -177 & 18 \\
\hline
\end{tabular}

Notes: Stars in the table denote significant effects $(* \mathrm{p}<0.1 ; * * \mathrm{p}<0.05)$; t-tests available upon the request. Data weighted by the weights provided by RSO.

\section{Ponudba dela in učinki ugodnosti zaposlenih na neenakost: ugotovitve za Srbijo}

\section{Izvleček}

Nizka udeležba na trgu dela skupaj z visokoučinkovito davčno obremenitvijo nizkih ravni plač ustvarja plodna tla za vpeljavo ugodnosti zaposlenih v Srbiji. Naš članek ponuja vnaprejšnjo oceno dveh shem ugodnosti zaposlenih, ki sta usmerjeni k spodbujanju ponudbe delovne sile in bolj enaki porazdelitvi dohodka. Metodološki pristop kombinira mikrosimulacijski model na osnovi davkov in koristi z diskretnim modelom ponudbe dela. Naši rezultati kažejo, da bi lahko tako individualne kot družinske sheme ugodnosti zaposlenih znatno okrepile sodelovanje na trgu dela, četudi bi lahko družinske ugodnosti imele nespodbudne učinke na drugega prejemnika dohodka. Večina vedenjskih sprememb se zgodi med najrevnejšimi posamezniki z znatnimi redistributivnimi učinki.

Ključne besede: ugodnosti iz naslova zaposlenosti, ponudba delovne sile, neenakost, model diskretne izbire, mikrosimulacija 